روش جديد بر آورد يارامترهاى هيدروليكى با اندازهيرى رطوبت خاك در مزرعه

شاهرخ زنديارسا"، سعيده يرويزى، عليرضا سِاسخواه و على اكبر كامخار حقيقى'

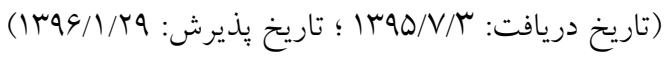

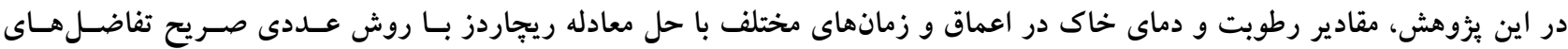

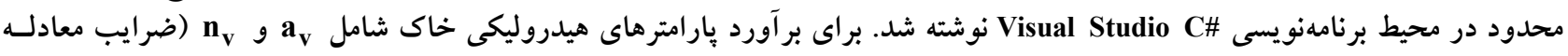

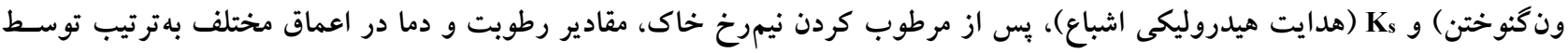

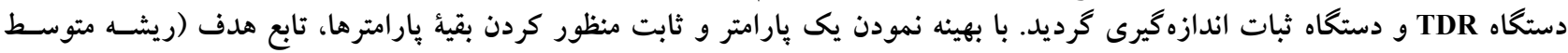

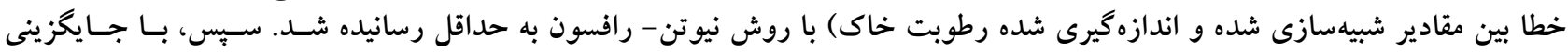

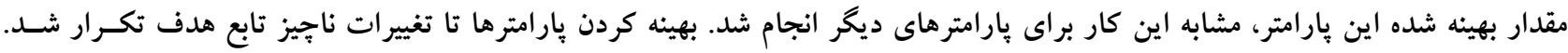

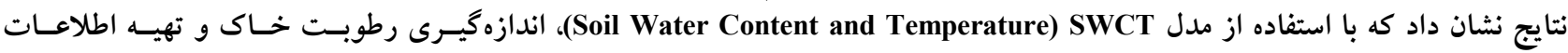

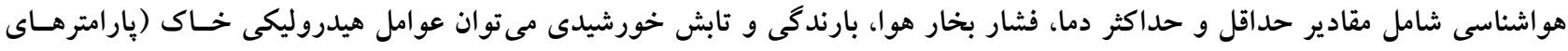

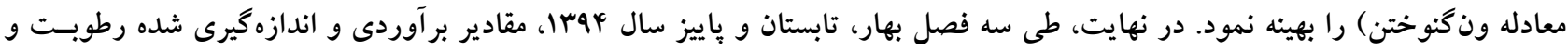

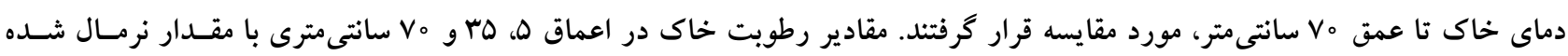

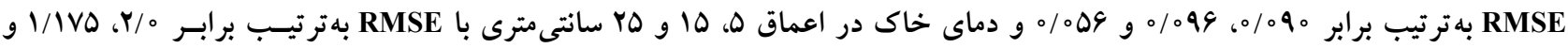

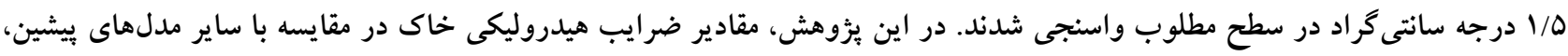

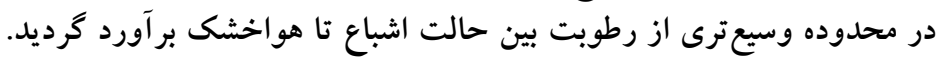

وازههاى كليدى: مدل SWCT، تابع هدف، روش معكوس، رطوبت خاك، دماى خاك

1. كروه مهندسى آب، دانشكدة كشاورزى، دانشخاه شيراز

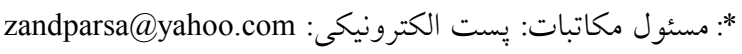


و فشـار آب خـاك در زمــانهـاى مختلــف اسـتفاده شــهـو و

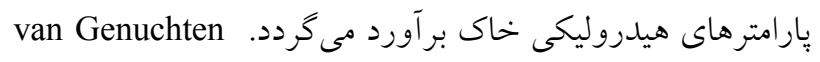

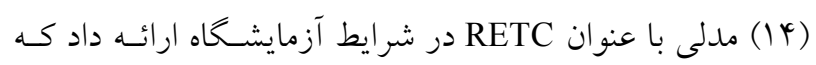

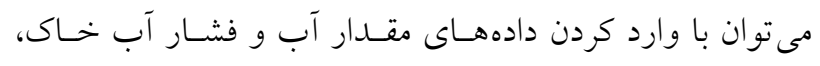

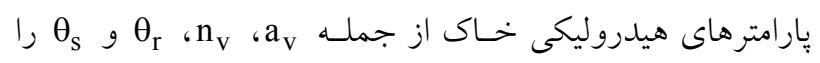

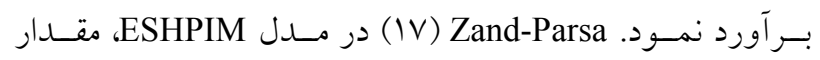

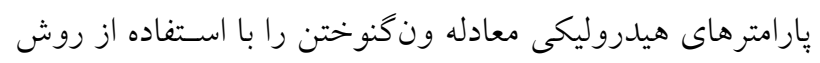

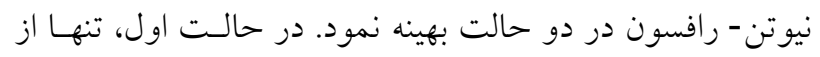

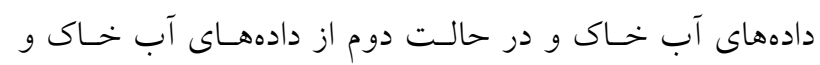

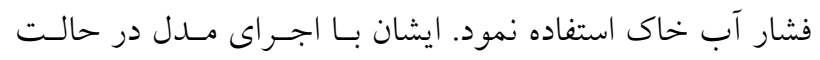
دوم به نتايج بهترى دست يافتند.

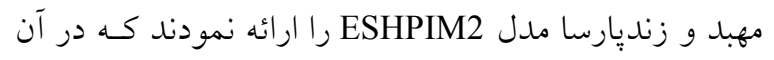

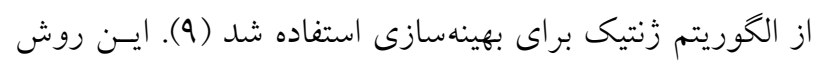

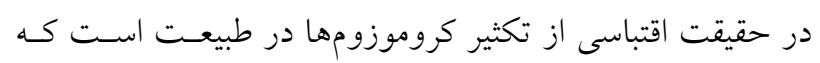

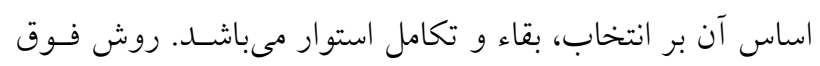

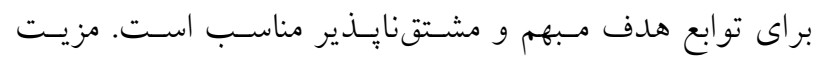

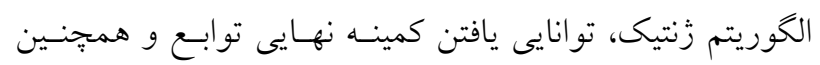

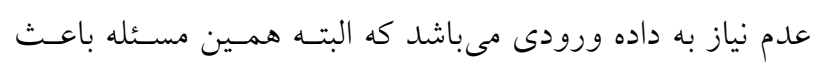

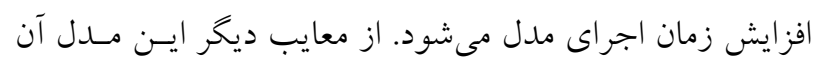

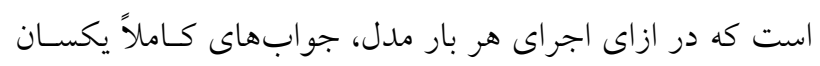

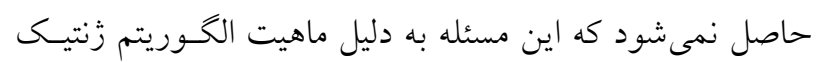

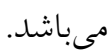

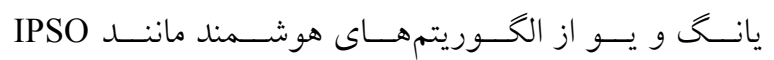
Improved Particle Swarm Optimization)

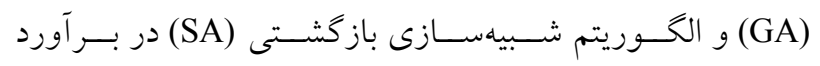

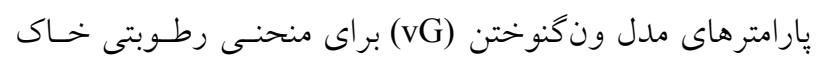

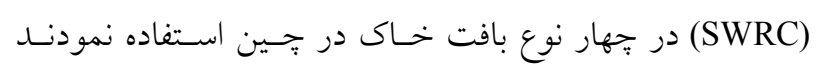

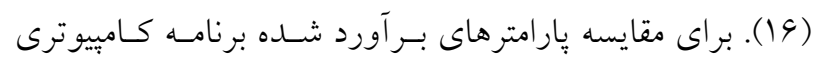

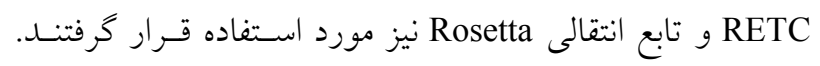

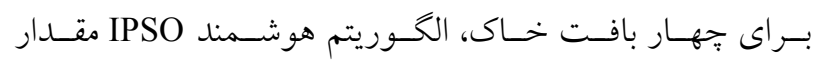

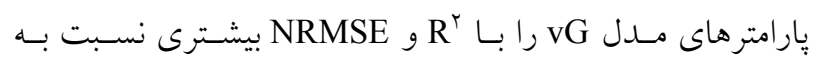

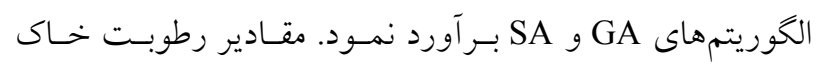

تاكنون مدلهاى مختلفى براى بيـان روابـط آب در خـاك ارائـهـ

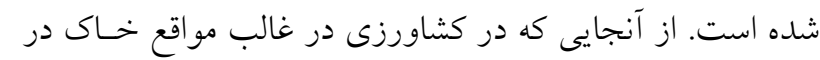

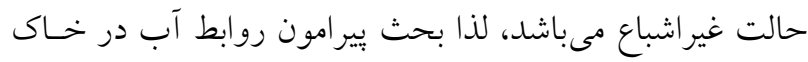
در حالت غيراشباع از اهميت بيشترى برخوردار اسـت. در تمـام

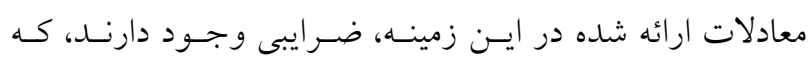

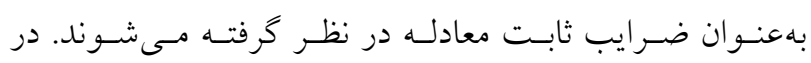

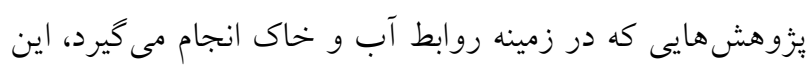
ضرايب را عوامل هيدروليكى مى نامند. در ميـان معـادلات ارائسه

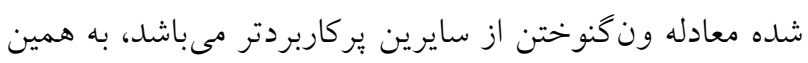

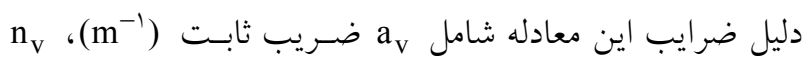
ضريب ثابت (بلدون بعد)،

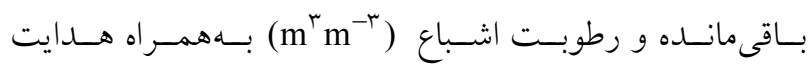

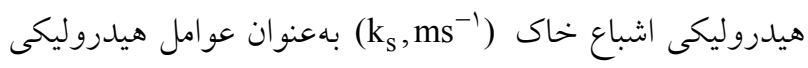

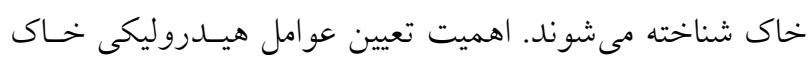

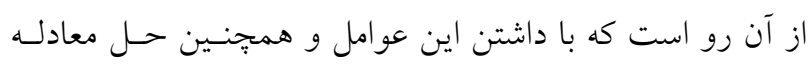

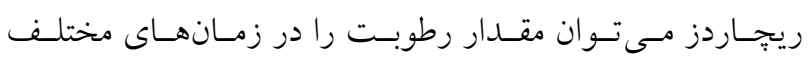

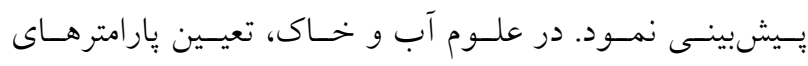

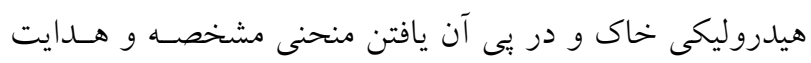
هيدروليكى خاك، نقش مهمى در محاسبات مربوط به اين علوم

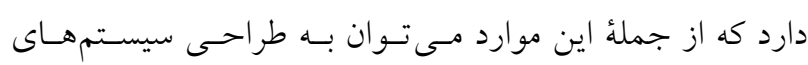

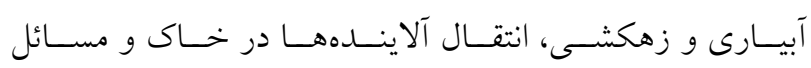
هيدرولوزى اشاره كرد.

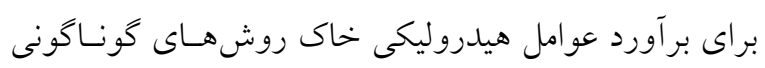

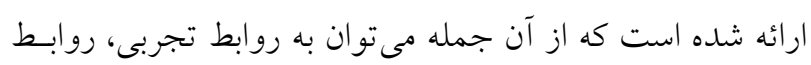

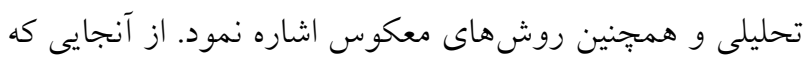

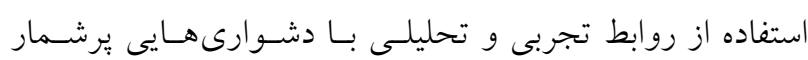

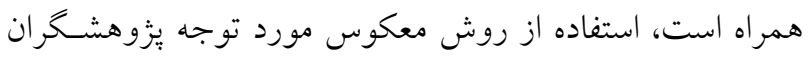

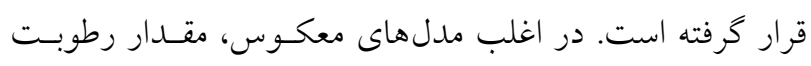

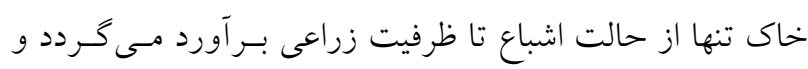

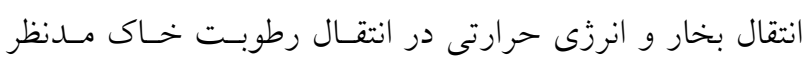
نيست. در واقع، در روش معكوس، از دادههاى مقدار آب خاك 
مقدار رطوبت و دماى خاك در شرايط زمين باير در اعماق مختلـف

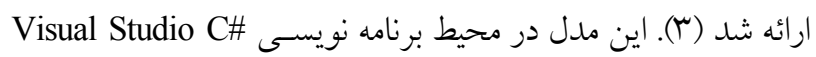
بازنويسى گرديد. فلوجارت مدل جديد، همراه با روش بهينهسـازى يارامترهاى هيدروليكى معادله ون گنـوختن در خـاك در شـكل (1) آورده شده است. اين مدل شامل يك برنامه اصلى و زيربرنامههـاى

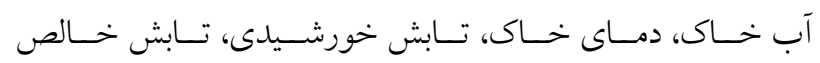
خورشيدى، تبخير و گرماى محسوس مىباشد.

\section{حركت آب مايع و بخار آب} آب در خاى در جهت كراديان هيـدروليكى حركـت مسى كنـد. معادلـه حــاكم بـر حركـت آب در خــاك در شـــايط اشـباع و غير اشباع، معادله دارسى مىباشد (V)). معادله حساكم بــر حركت يكبعدى آب مايع و بخار آب در منافذ خاك (درجهت عمودى و منفى در جهت پيايين) بهصورت زير است (r) (I): $\frac{\partial \theta}{\partial \mathrm{t}}=-\frac{\partial \mathrm{q}_{\mathrm{L}}}{\partial \mathrm{Z}}-\frac{\partial \mathrm{q}_{\mathrm{V}}}{\partial \mathrm{Z}}-\mathrm{SW}$

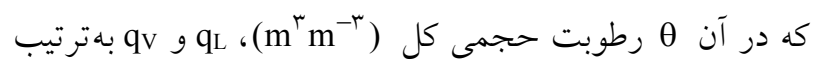

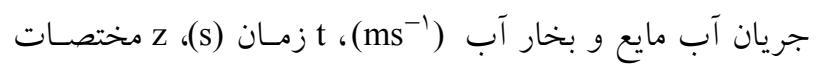
عمودى مثبت در جهت رو به بالا (m) و SW ميزان جذب (كـه بهطور معمول عبارت است از جذب آب توسط ريشه در واحسـ حجم در واحد زمان) (s-1) مسىباشـند. رطوبـت حجمسى كـل

$$
\text { بهصورت زير تعريف مى گردد: }
$$

$\theta=\theta_{\mathrm{L}}+\theta_{\mathrm{V}}$ كه در آن رطوبـت حجمسى بخــار آب $\theta_{v}$ شبيهسازى جريان آب بهصورت مـايع تحست اثـر ثقـل و دمـاى

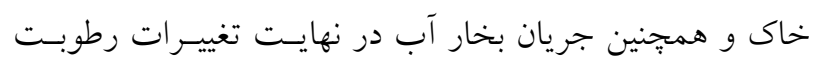

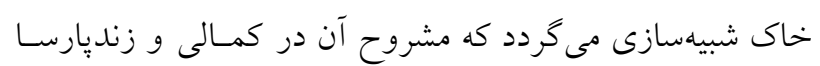

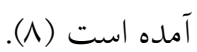

انتقال گرما در خاى مدل انتقال گرما، تفكيك انرزى گرمايى در لايه سطحى خاك و
شبيهسازى شده بهوسيله IPSO با R برابر 99/ بسـيار نزديـك

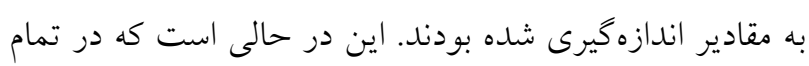
الخوريتمها، مقدار رطوبت باقى مانده خاى ( آوردن نبود. كمالى و زنديارسا مدل EISHP را جهت بــــآورد پِارامترهـاى هيدروليكى خاى به روش معكوس با استفاده از بهينه نمودن هـر

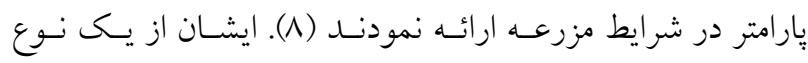
روش رياضى براى كمينه كردن تابع هدف اسـتفاده كردنـــ. مــل

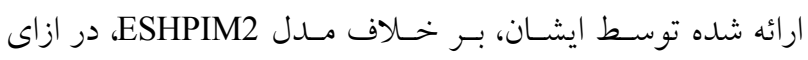
ورودىهاى مختلف، جوابـهاى يخانسهاى نتيجـه داد. نكتـه قابـل توجه اين بود كه تفاوتهاى ناجيز تابع هدف مى توانست باعـث ايجاد تفاوتى جشمخير در يار امترهاى هيـدروليكى شـود. در ايسن مدل، بهينهسـازى حاصل نمى كرد. بنابراين Kamali و Zand-Parsa يبشنهاد نمودنــ

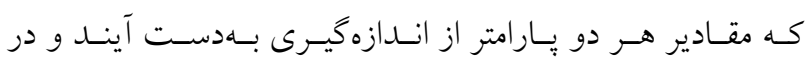
بهينهسازى دخالت داده نشوند (N).

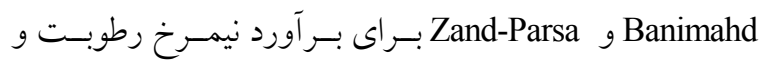
دماى خاى با منظور كردن جريان مايع و بخار آب در شرايط زمسين بـاير، مــل Soil Water Content and Temperature) SWCT ارائه نمودند (r). در اين مدل، مقدار رطوبت خاك از حالـت اثـباع

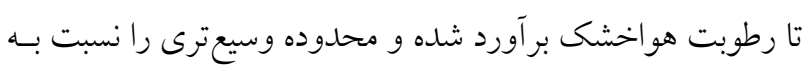
ساير مدلها در بر مى گيـرد. در مـدل SWCT، معـادلات بـا روش

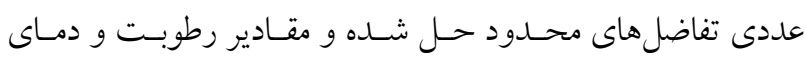
خاى در اعماق و زمانهاى مختلف برآورد مىشوند.

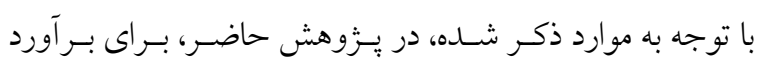
يار امترهاى هيــروليكى معادلـه ون گنـوختن در خــاك بـا اسـتفاده از روش بهينه سازى هر بارامتر، از مدل SWCT استفاده گرديد كه انتقـال بخار و انرزى حرارتى را در انتقال رطوبت خاك در نظر مى گيرد. مواد و روش ها ساختار مدل مدل SWCT در محيط برنامهنويسى 6.0 Visual Basic براى برآورد 


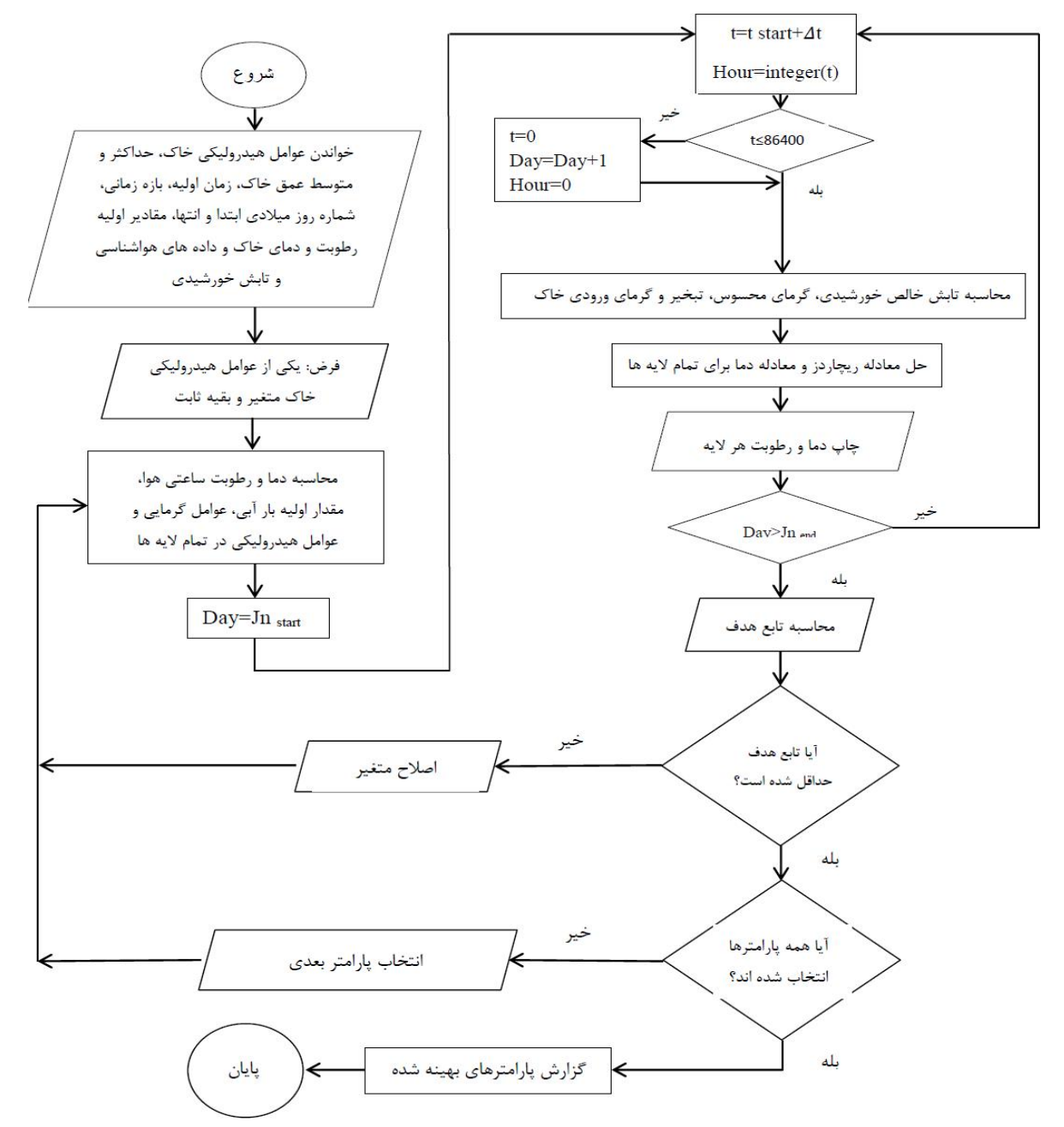

شكل ا. فلوحارت مدل SWCT همراه با روش بهينهسازى عوامل هيدروليكى معادله ونكنوختن در خاك

توزيع دماى خاك را توصيف مىنمايد. تفكيك انـرزى گرمايى تعادل انرزى سطحى

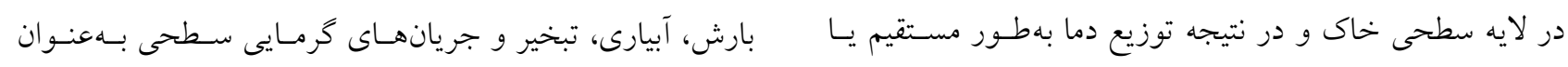

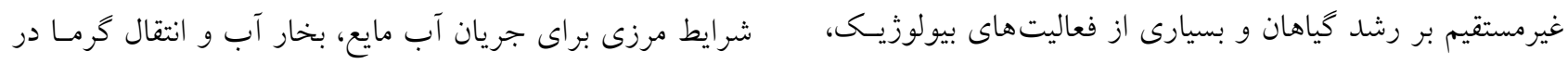

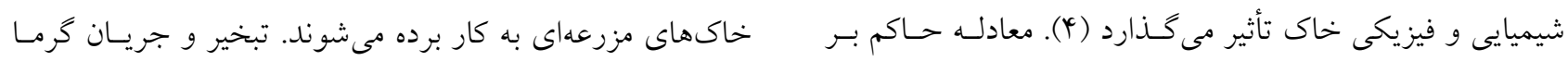

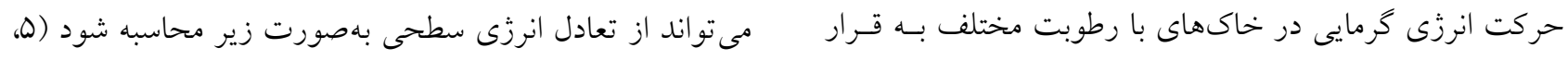
ما و (1): زير است (Y) (I): $\mathrm{R}_{\mathrm{n}}-\mathrm{H}-\mathrm{LE}-\mathrm{G}=$ 。

$\left[{ }^{\mathrm{c}}\right] \quad \frac{\partial \mathrm{S}_{\mathrm{h}}}{\partial \mathrm{t}}=-\frac{\partial \mathrm{q}_{\mathrm{h}}}{\partial \mathrm{z}}-\mathrm{Q}$

كـهـ

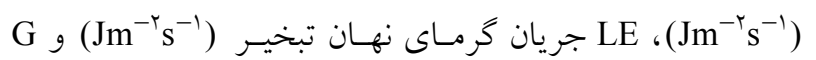
جريان كرماى خاك $)$ (Jm رو به بايين مثبت و H و LE در جهت رو به بالا مثبت هستند. كه Sh ذخيره گرما در خـاك (

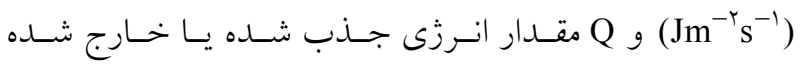
مى باشند. $\left(\mathrm{Jm}^{-r} \mathrm{~s}^{-1}\right)$ 


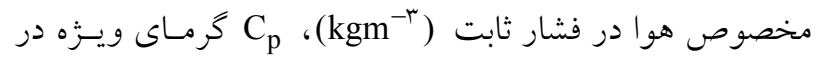

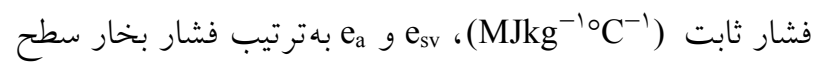

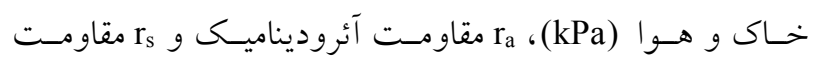
سطحى خاى در برابر تبخير مىباشند. $\left(\mathrm{kPa}^{\circ} \mathrm{C}^{-1}\right)$

\section{تابع هدف}

براى برآورد بِارامترهاى هيـدروليكى خـاك بـهـ روش معكسوس

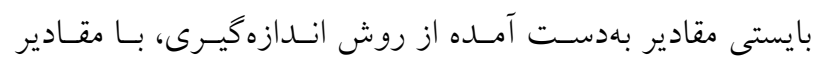

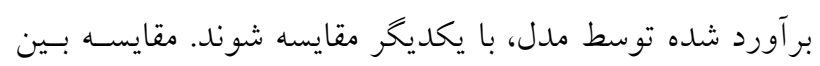

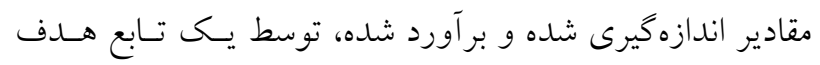

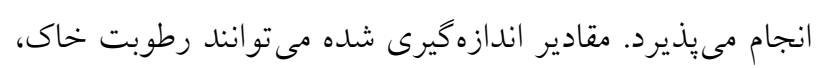

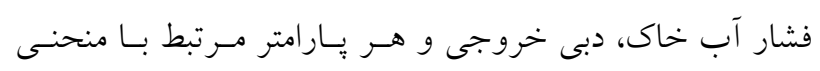

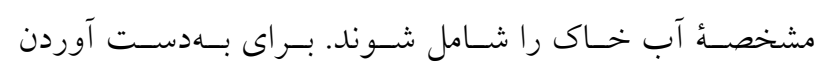
مناسبترين مقادير برآوردى، بايستى از يكى سرى معادلاتى كـهـ

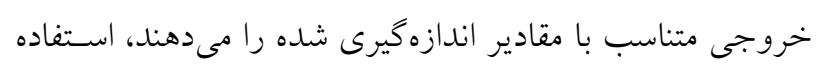

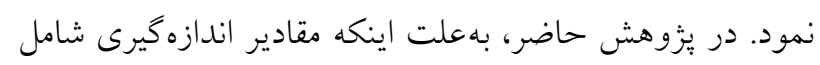

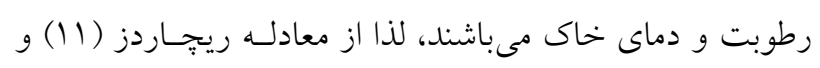

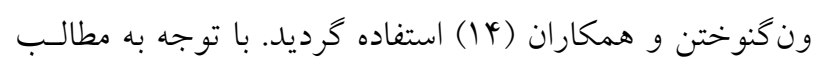

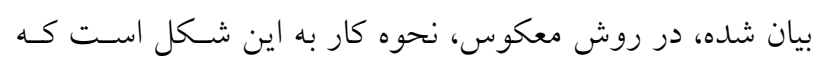
يار امترهاى هيدروليكى خـاك

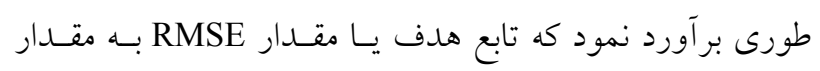

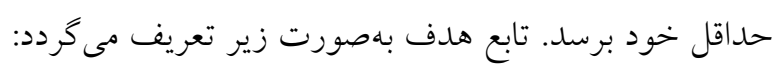

$$
\operatorname{RMSE}=\left(\frac{\sum_{1}^{n_{1}} \sum_{1}^{n_{r}}\left(\theta_{i, j}^{o}-\theta_{i, j}^{c}\right)^{r}}{n_{1} \times n_{r}}\right)^{\circ / \Delta}
$$

كه $\theta$ رطوبت خاى

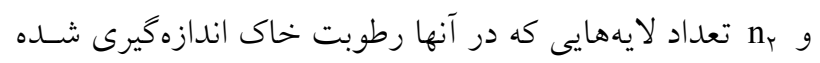

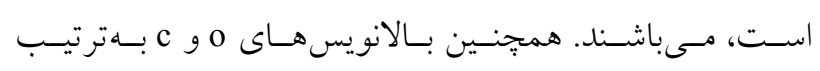

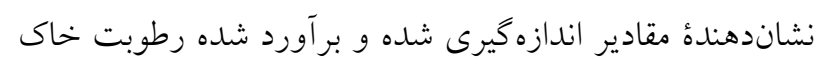

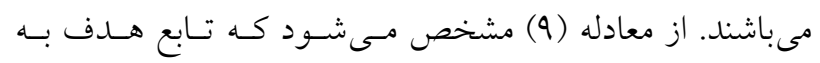

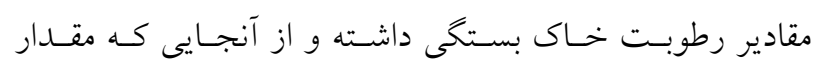

تابش

تابشى كه به يك سطح عمود بر يرتوهاى خورشسيدى در بـالاى

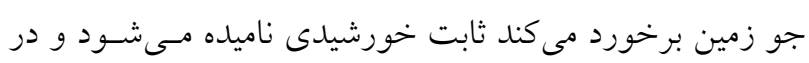

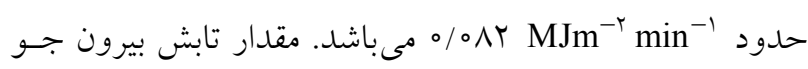
وابسته به زاويه بين برتوهاى خورشيد و سطح زمين مسىباشــــ

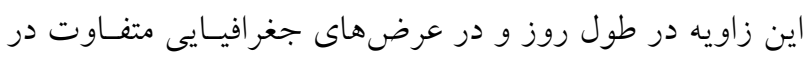

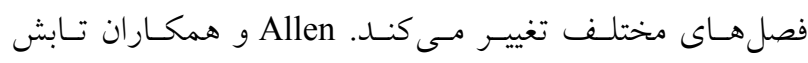
خورشيدى رسيده به سطح افقى در بالاى جو زمين را بـهـعنـوان

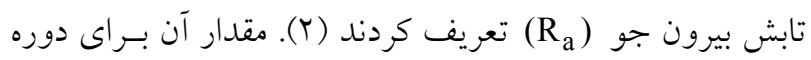

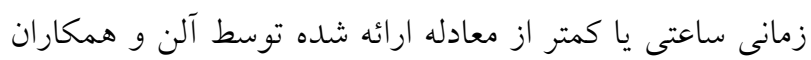

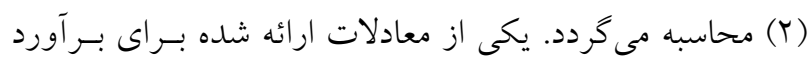

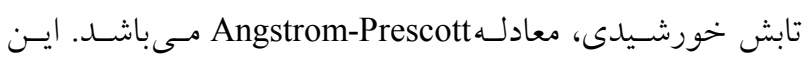

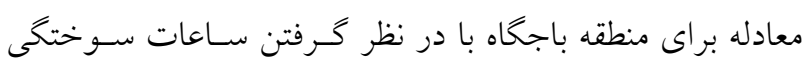

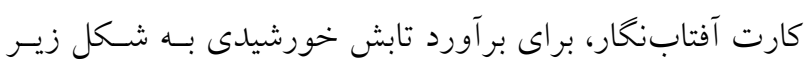

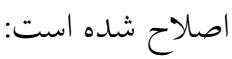

$\mathrm{R}_{\mathrm{s}}=\mathrm{R}_{\mathrm{a}}\left(0 / \mu<\varphi+0 / 490 \frac{\mathrm{t}_{\mathrm{s}}}{\varphi_{0}}\right)$

(Jm $\left.{ }^{-r} \mathrm{~s}^{-1}\right)$ تابش خورشيدى يا تابش طول موج كوتساه

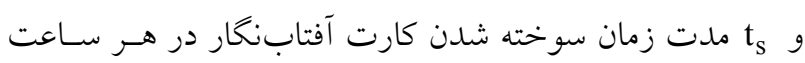

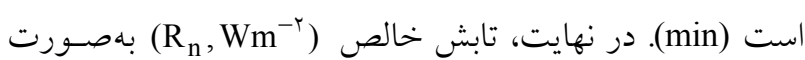

زير تعيين مى خردد (4):

$\mathrm{R}_{\mathrm{n}}=\mathrm{R}_{\mathrm{ns}}-\mathrm{R}_{\mathrm{nl}}$

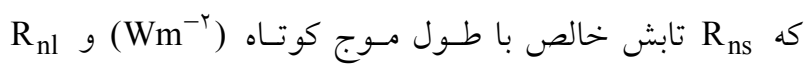
تابش خالص با طول مـوج بلنــ (Wm

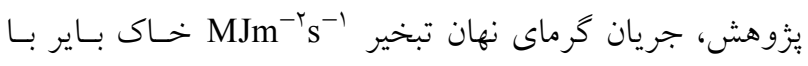

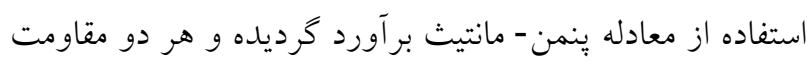

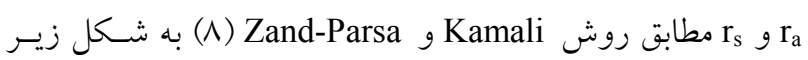
بر آورد مى آشوند:

$\mathrm{LE}=\frac{\Delta\left(\mathrm{R}_{\mathrm{n}}-\mathrm{G}\right)+\rho_{\mathrm{a}} \mathrm{C}_{\mathrm{p}}\left(\left(\mathrm{e}_{\mathrm{sv}}-\mathrm{e}_{\mathrm{a}}\right) / \mathrm{r}_{\mathrm{a}}\right)}{\Delta+\gamma_{\mathrm{s}}\left(1+\left(\mathrm{r}_{\mathrm{s}} / \mathrm{r}_{\mathrm{a}}\right)\right)}$

كه د شيب منحنى فشـار بخـار اشـباع در برابـر دمـاى خـاك

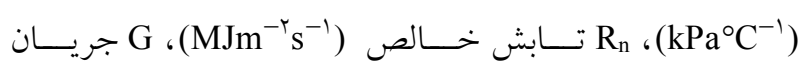

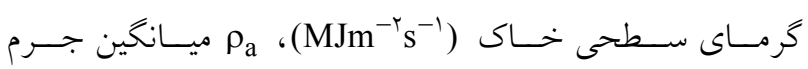


خـاك توسط دسـتخاه دمانخـار نـوع Ua 258 سـاخت شـركت Lشور آلمان انجام شد. بروب مهاى دستخاه TDRbrecht

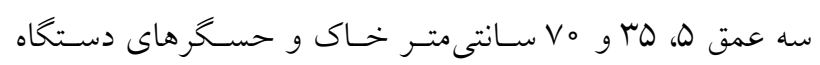

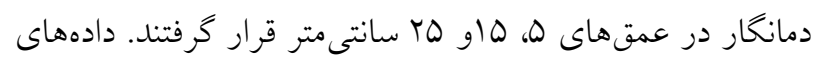

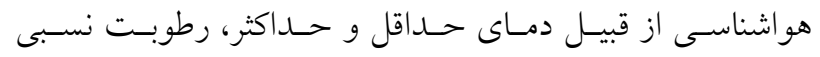
حداقل و حداكثر، سرعت باد و بارش در ماههاى مختلف بهك دهار

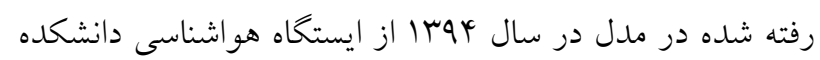

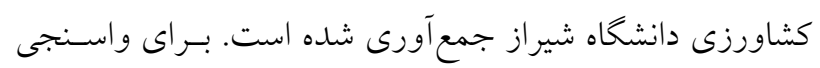
مدل از دادههاى فوق استفاده شد.

\section{بررسى آمارى بين نتايج اندازهيرى شده و بر آورد شده} اولين شاخص آمارى كه براى برآورد كردن عملكرد مدل بهـ بهـار

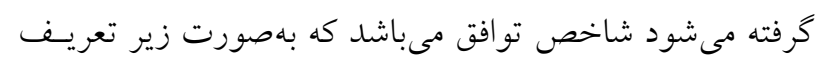
مى كردد:

$$
d=1-\left[\frac{\sum_{i=1}^{n}\left(P_{i}-O_{i}\right)^{r}}{\sum_{i=1}^{n}\left(\left|P_{i}-\bar{O}\right|+\left|O_{i}-\bar{O}\right|\right)^{r}}\right]
$$

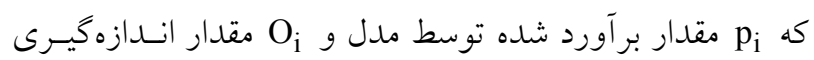

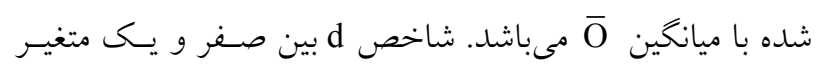

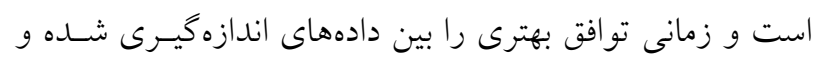

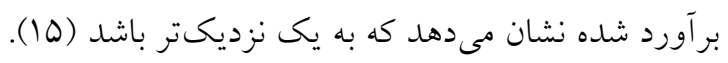

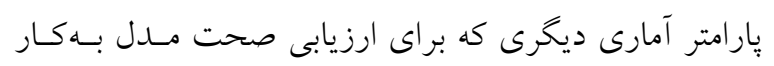

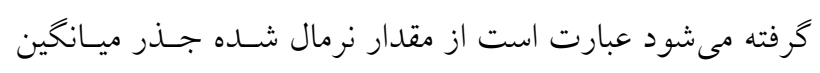
مربعات خطا كه بهصورت زير بيان مى خردد: NRMSE $=\frac{\sqrt{\sum_{\mathrm{i}=1}^{\mathrm{n}} \frac{\left(\mathrm{P}_{\mathrm{i}}-\mathrm{O}_{\mathrm{i}}\right)^{r}}{\mathrm{n}}}}{\overline{\mathrm{O}}}$

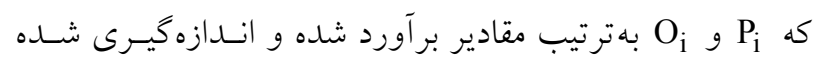
پارامترها، n تعداد كل دادهها و

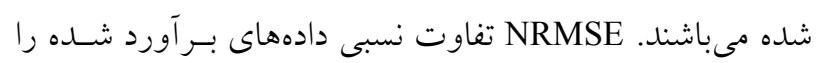
در برابر دادهاى اندازهگيرى شده نشان مى دهد. مقادير بـر آورد

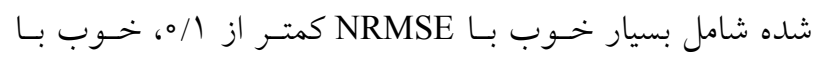

رطوبت خاك نيز به خصوصيات هيدروليكى خاك وابسته است،

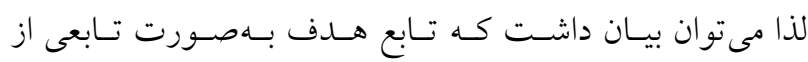

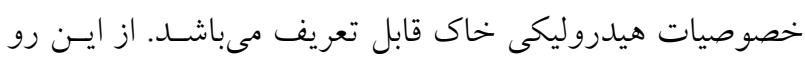
تابع هدف را مىتوان بلصورت جداكانه بهينه نمود.

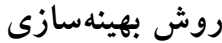

براى يافتن خصوصيات هيدروليكى خـاك بـهـ روش معكـوس،

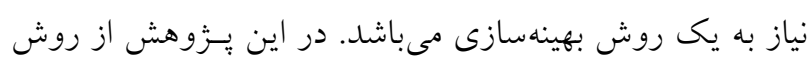

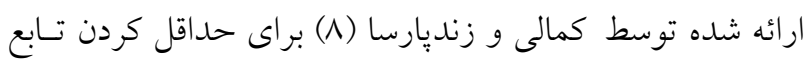

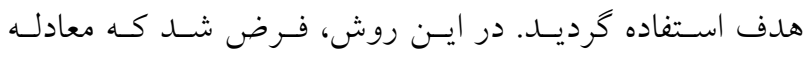

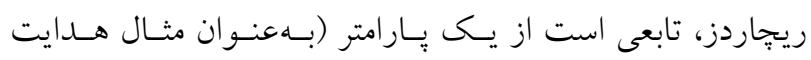

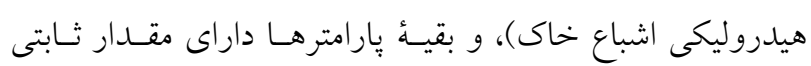

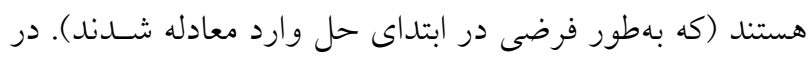

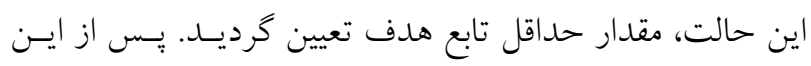

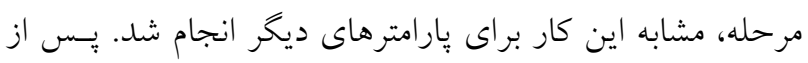

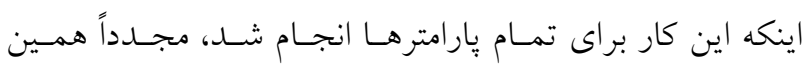

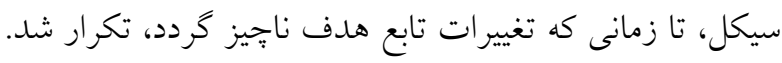

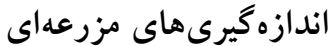

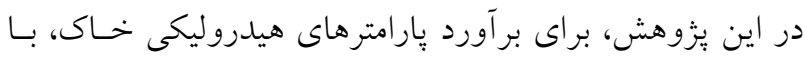

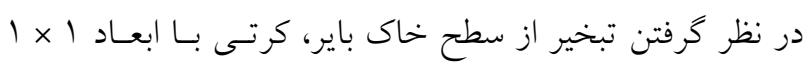

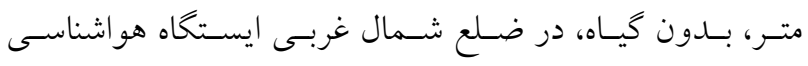

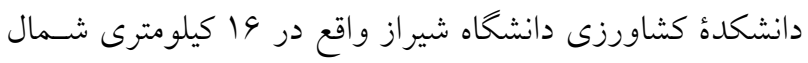

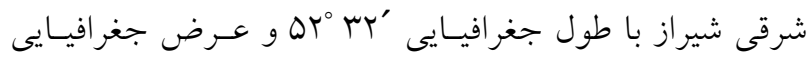

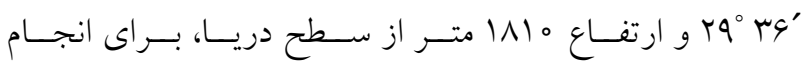

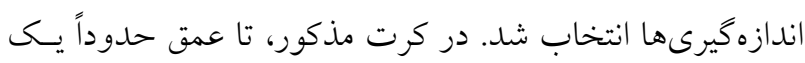
متر، رطوبت خاك نزديك به اشباع رسانيده شد. به دليـل بـايين

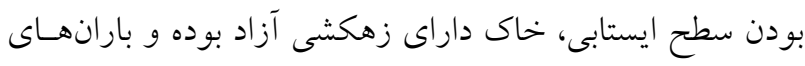

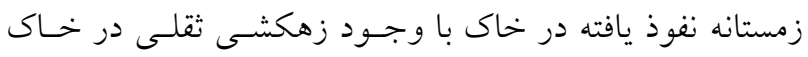

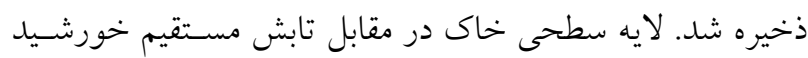

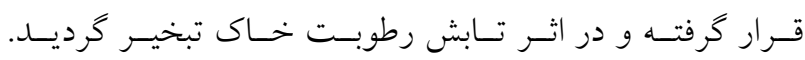

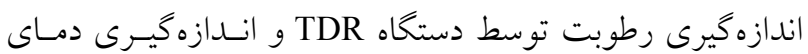


هيدروليكى خاك شامل

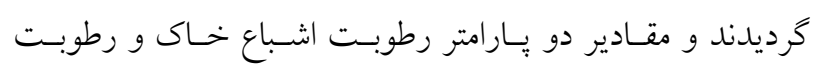

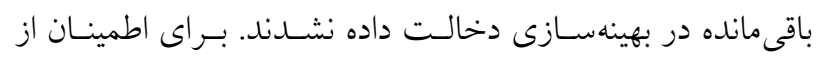

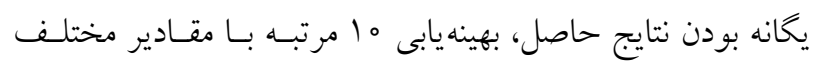

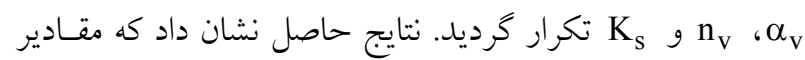

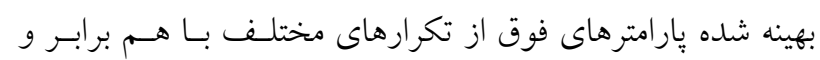

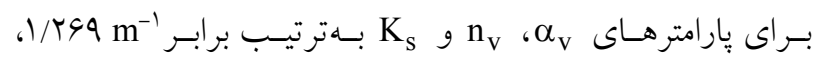

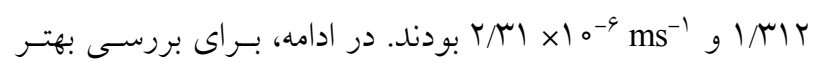

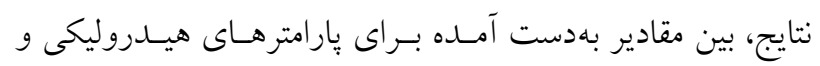

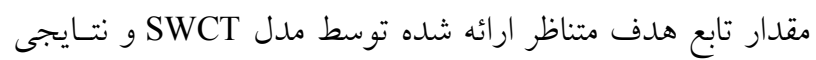

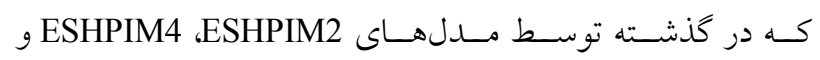
ESHPIM5 بهدست آمده است، مقايسهاى صسورت كرفـت. ايسن

$$
\text { نتايج به شكل جدول (1) كزارش شده است. }
$$

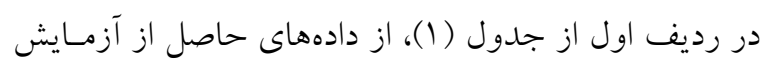

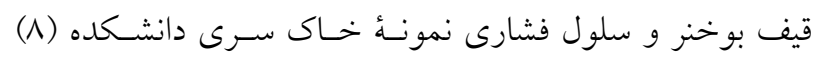

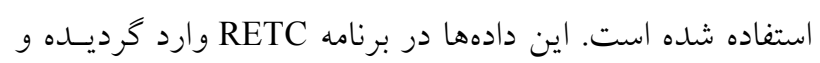

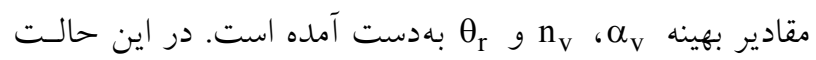

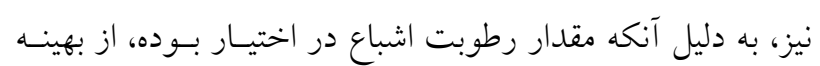

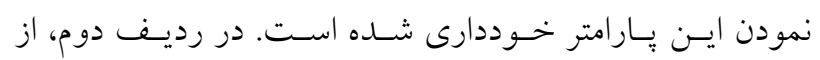

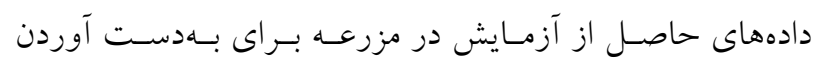

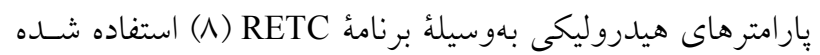

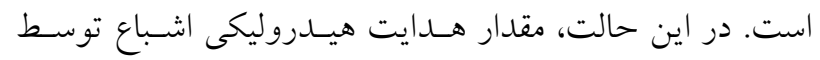

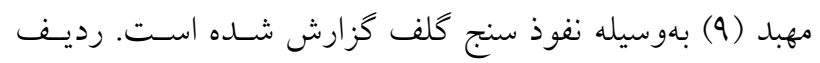

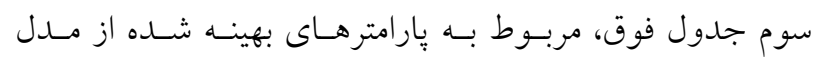
ESHPIM2

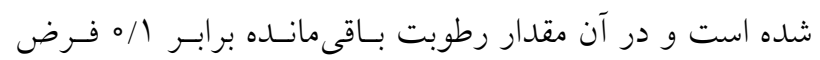
شده بود.

در رديفهاى جهارم، ينجم و ششم نتسايج حاصـل از مــدل

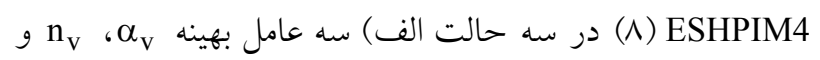

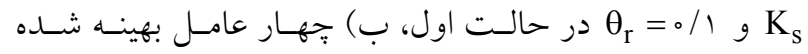

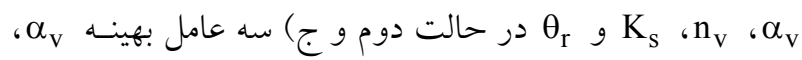

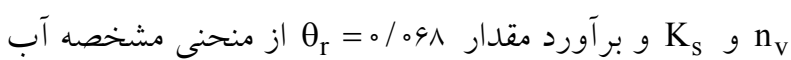

NRMSE بين // الى / /ه ، نسبتاً خوب بـا NRMSE بـين r/

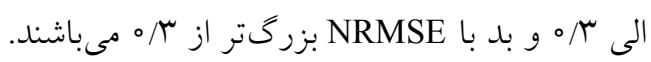

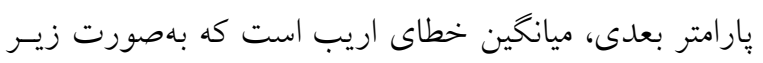
محاسبه مىشود (10): (10)

$\mathrm{MBE}=\frac{1}{\mathrm{n}} \sum_{\mathrm{i}=1}^{\mathrm{n}}\left(\mathrm{P}_{\mathrm{i}}-\mathrm{O}_{\mathrm{i}}\right)$ زمانى كه ميانخين خطاى اريب (MBE) صفر باشد، نشاندهنــه

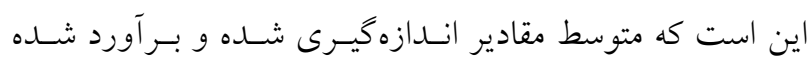
برابر هستند. اكر مقدار MBE مثبت كردد، يعنى مقــادير بـر آورد

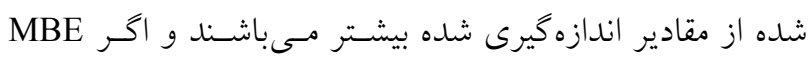

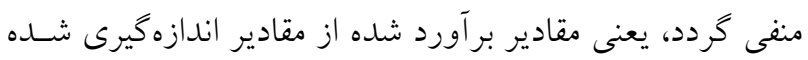

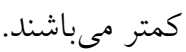

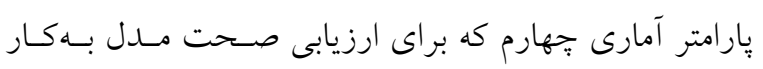

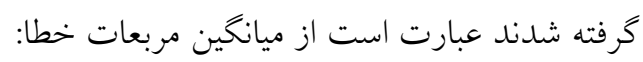
RMSE $=\sqrt{\sum_{\mathrm{i}=1}^{\mathrm{n}} \frac{\left(\mathrm{P}_{\mathrm{i}}-\mathrm{O}_{\mathrm{i}}\right)^{r}}{\mathrm{n}}}$

هرجه مقدار RMSE كمتر باشــ نشـانه تطـابق بهتــ مــدل بـا مقادير اندازهيرى شده مىباشد.

\section{نتايج و بحث}

بهينهسازى بارامترهاى منحنى مشخصه آب خاك با باستـفاده از مدل SWCT

مدل SWCT، با اعمال دادههاى ورودى مورد نياز شامل دادههـاى

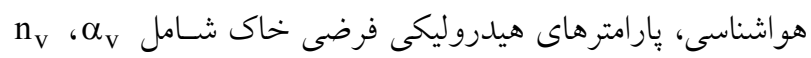

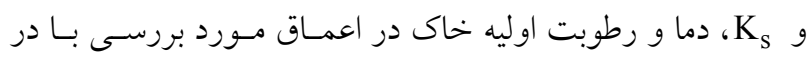

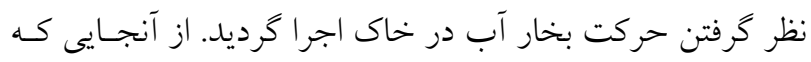

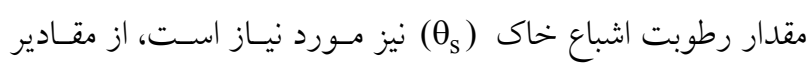

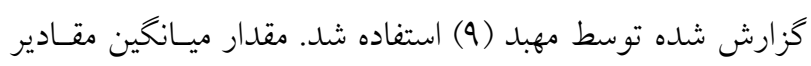

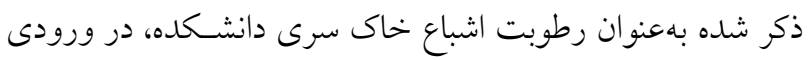
مدل SWCT قرار گرفت. مقدار رطوبت باقى مانده (

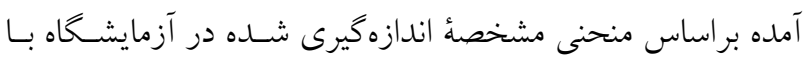

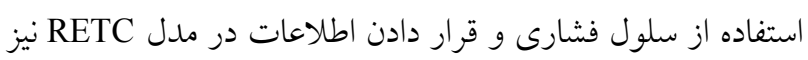

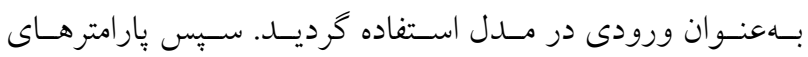


جدول ا. مقايسه بين مقادير تابع هدف (RMSE) بهدست آمده از مدل SWCT با در نظر گرفتن حركت بخار آب در خاك، براى سه عامل

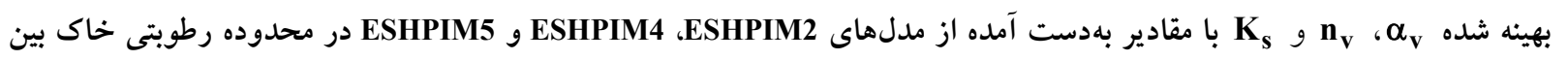

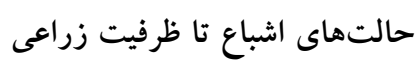

\begin{tabular}{|c|c|c|c|c|c|c|}
\hline$\Theta_{\mathrm{r}}$ & $\Theta_{\mathrm{s}}$ & $\mathrm{n}_{\mathrm{v}}$ & $\alpha_{\mathrm{v}}$ & $\mathrm{K}_{\mathrm{s}}$ & RMSE & روش \\
\hline$\left(\mathrm{m}^{r} \mathrm{~m}^{-r}\right)$ & $\left(\mathrm{m}^{r} \mathrm{~m}^{-r}\right)$ & & $\left(m^{-1}\right)$ & $\left(\mathrm{m} \mathrm{s}^{-1}\right)$ & $\left(\mathrm{m}^{r} \mathrm{~m}^{-r}\right)$ & \\
\hline $0 / 09 \Lambda$ & o/kr & $1 /$ TیS & (T/N & - & - & $\begin{array}{c}\text { RETC } \\
\text { با اطلاعات آزمايشخاه }\end{array}$ \\
\hline$\circ / \circ \circ \circ$ & $0 /$ M & $1 / 09 \Lambda$ & $\circ / \mathrm{VI} \circ$ & $r /|r \times| 0^{-9}$ & - & $\begin{array}{c}\text { RETC } \\
\text { با اطلاعات مزرعه }\end{array}$ \\
\hline$\circ / 100$ & $0 / 4 x$ & $|/ M| \Lambda$ & $1 / 490$ & $r / 9 Y \times 10^{-9}$ & $r / Y \Delta r \times 10^{-r}$ & مهبد، حالت اول \\
\hline$\circ / 100$ & o/kr & 1/RTr & 1/אG & $r / T \Delta \times 10^{-9}$ & $r / 419 \times 10^{-r}$ & كمالى، حالت اول \\
\hline$\circ / 000$ & o/kr & $1 / T \wedge \Delta$ & $1 / 140$ & $T / Y 9 \times 10^{-9}$ & $r / M \varphi V \times 10^{-r}$ & كمالى، حالت دوم \\
\hline $0 / 09 \Lambda$ & $0 /$ Kr & $|/ \mu| \Lambda$ & $1 / 791$ & $T / M Y \times 10^{-9}$ & $r / 4 \circ r \times 10^{-r}$ & كمالى، حالت سوم \\
\hline$\circ / 100$ & o/ & $1 / \mu_{Y} \wedge$ & $1 / Y 0 Q$ & $9 / T V \times 10^{-9}$ & $r / M q Y \times 10^{-r}$ & ميرصفى، حالت اول \\
\hline $0 / 09 \Lambda$ & $0 /$ Kr & מצr & $1 / 190$ & $N / \Delta r \times 10^{-v}$ & $r / M V Y \times 10^{-r}$ & ميرصفى، حالت سوم \\
\hline $0 / 091$ & $0 / 4 r$ & $1 / \pi \mid r$ & $1 / 499$ & $r / \mu \mid \times 10^{-9}$ & $r / r \mu r \times 10^{-r}$ & SWCT \\
\hline
\end{tabular}

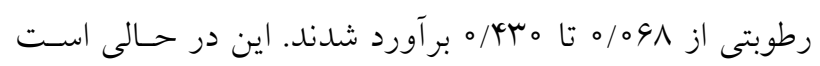

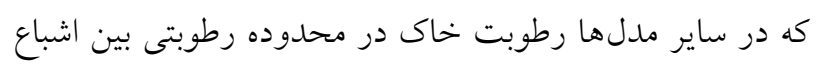

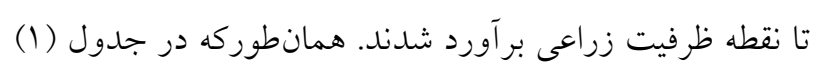

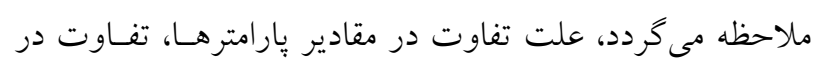

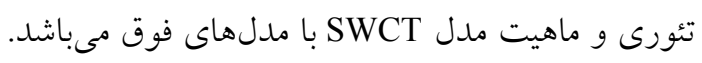

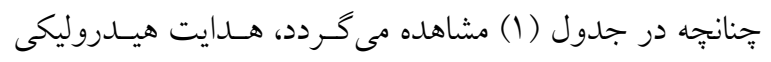

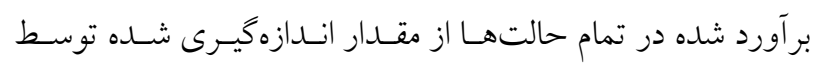
نفوذسنج كلف كمتر مىباشد. براى توجيه اين مسئله مى توان به اين

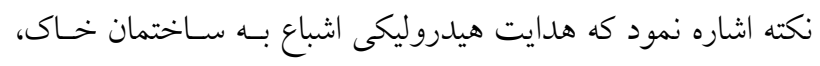

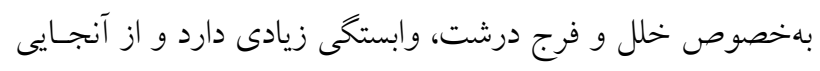

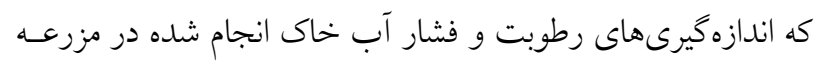

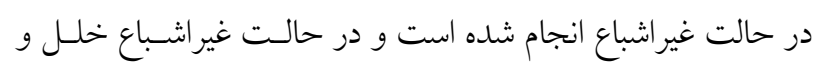

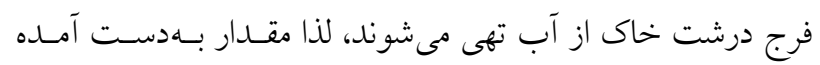

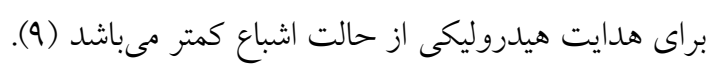

رطوبت بر آورد شده خاك مدل SWCT با اعمـال دادههـاى ورودي مـورد نيـاز در اعمـاق
خاى در حالت سوم گردآورى شده است.

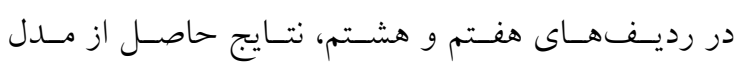

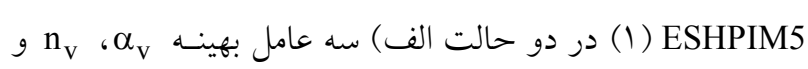

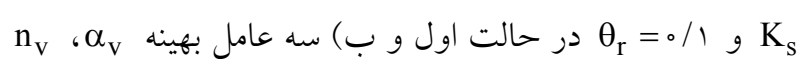

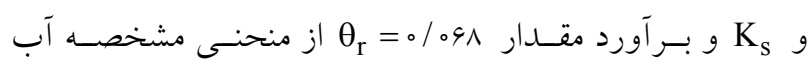
خاك در حالت سوم درج گرديده است. در رديف نهم از جدول فوق، نتايج حاصل از مـدل SWCT

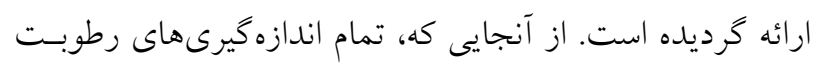

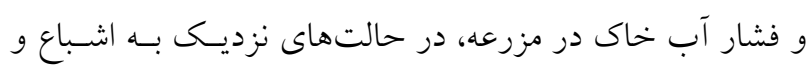

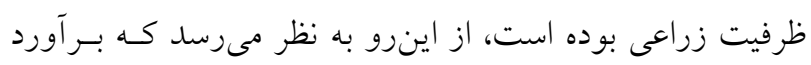

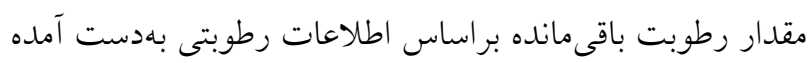

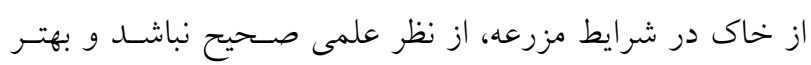

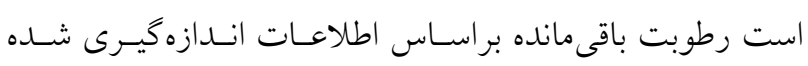

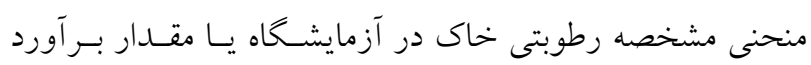

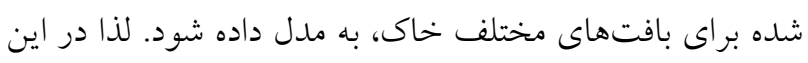
يزوهش نيز، رطوبت باقى مانده در بهينهسازى دخالت داده نشد.

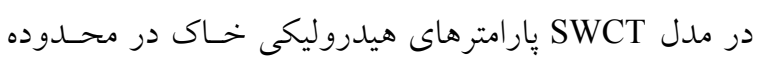


حركت بخار آب كم مىباشد، ولى اين مقــار كـم نيـز در لايـهـ

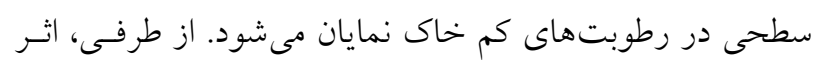

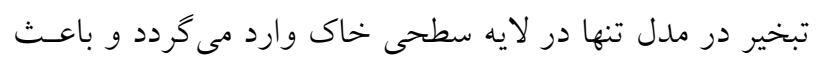

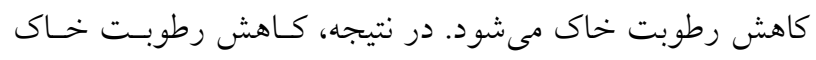

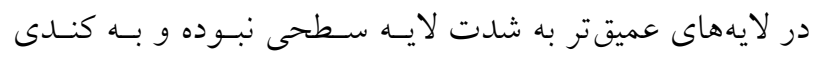

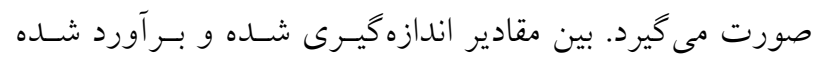

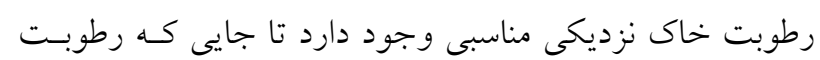

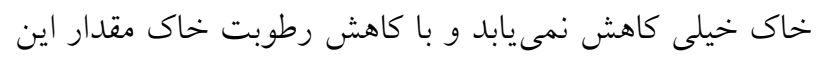

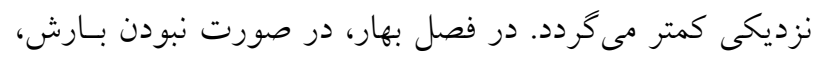

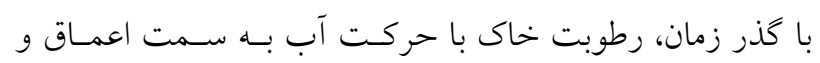

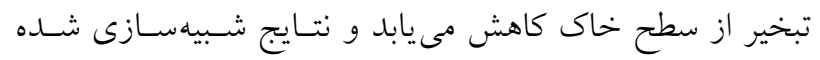
مدل SWCT به خوبى قادر به نشـان دادن رونـــ ايسن تغييـرات

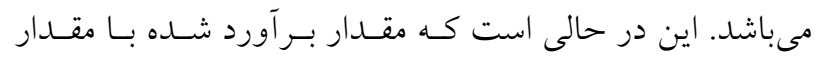
اندازهيرى شده آن اندكى تفاوت دارد و اين موضـوع در در تمـام لايههاى مورد بررسى مشاهده مىشود.

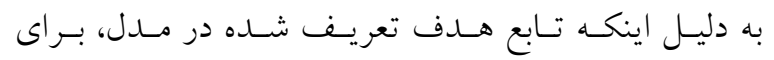

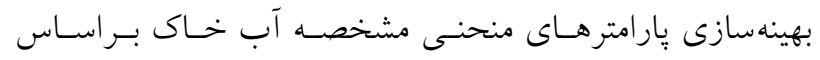

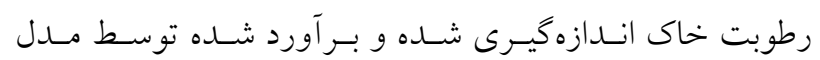

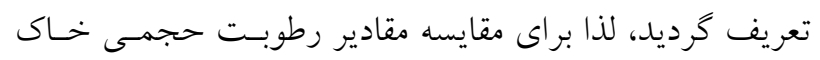

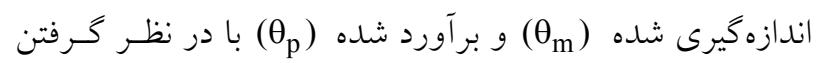

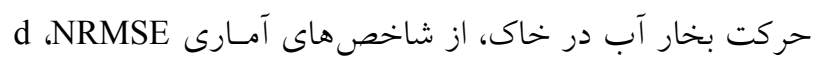

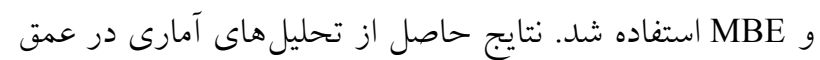

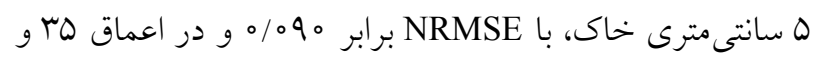

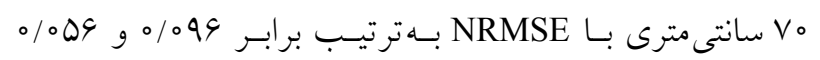

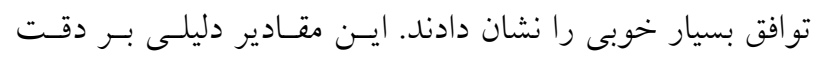

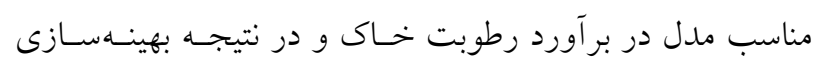

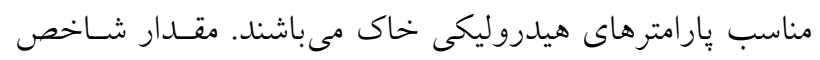

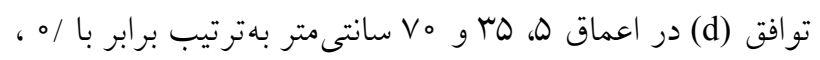

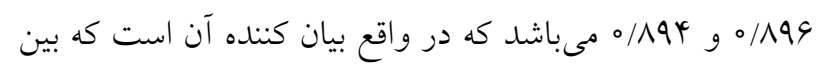

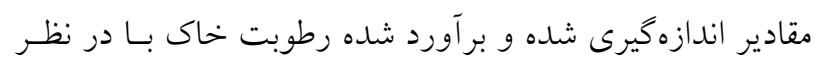

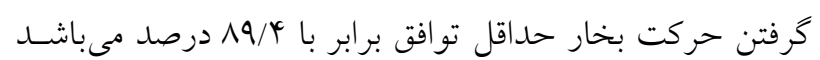

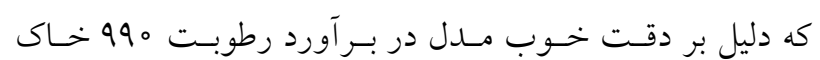

مورد بررسى اجرا گرديســ و مقـادير رطوبـت خهـاك بـا در نظــ

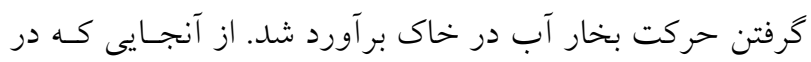
اين مدل برخلاف ساير مدلهايى كه تاكنون در اين زمينـه ارائسه

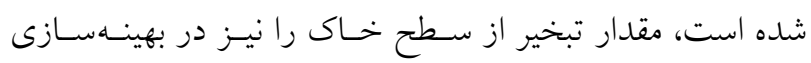

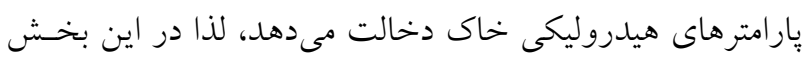

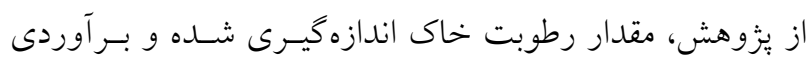

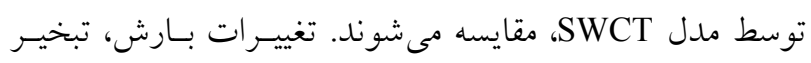

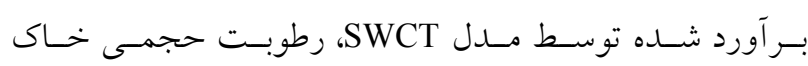
اندازهيرى شده و برآورد شده با در نظر كـرفتن حركـت بخــار

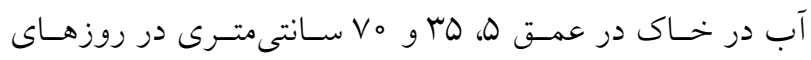

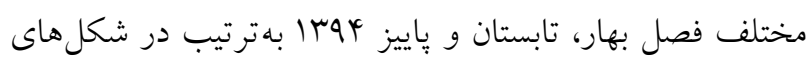

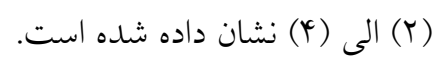

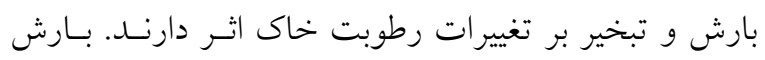

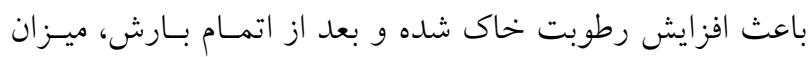

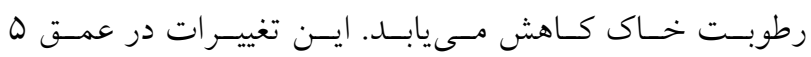

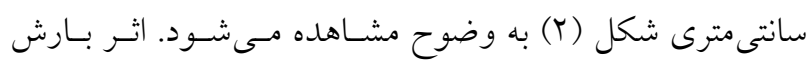

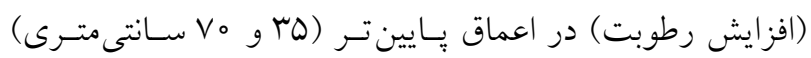

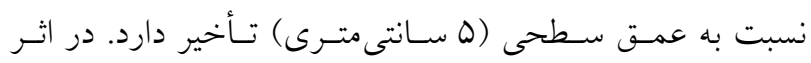

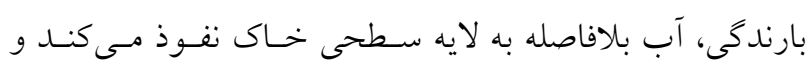

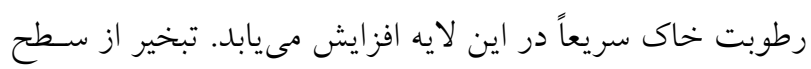

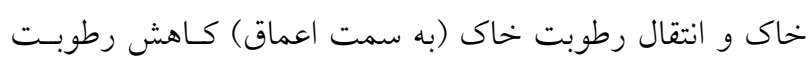

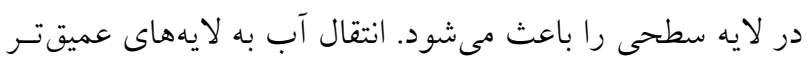

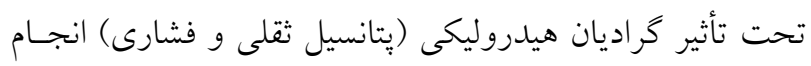

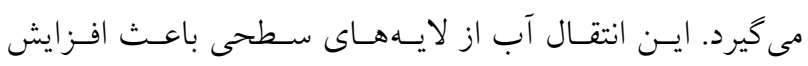

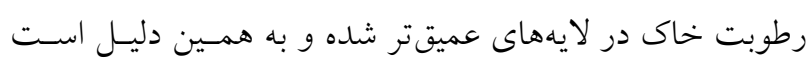
كه افزايش رطوبت در لايههاى عميقتر نسبت به لايه سطحى با بائ

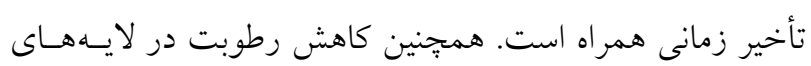

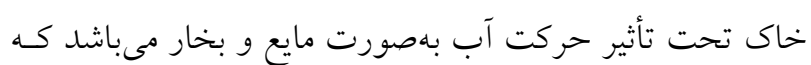

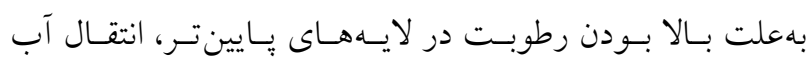
بهاصورت بخار كمتر مى باشد و مؤثرترين عامل كاهش رطوبـت

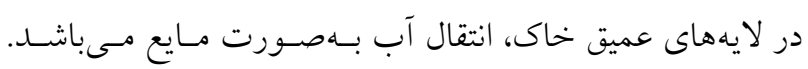

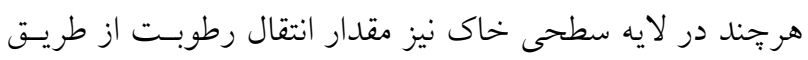



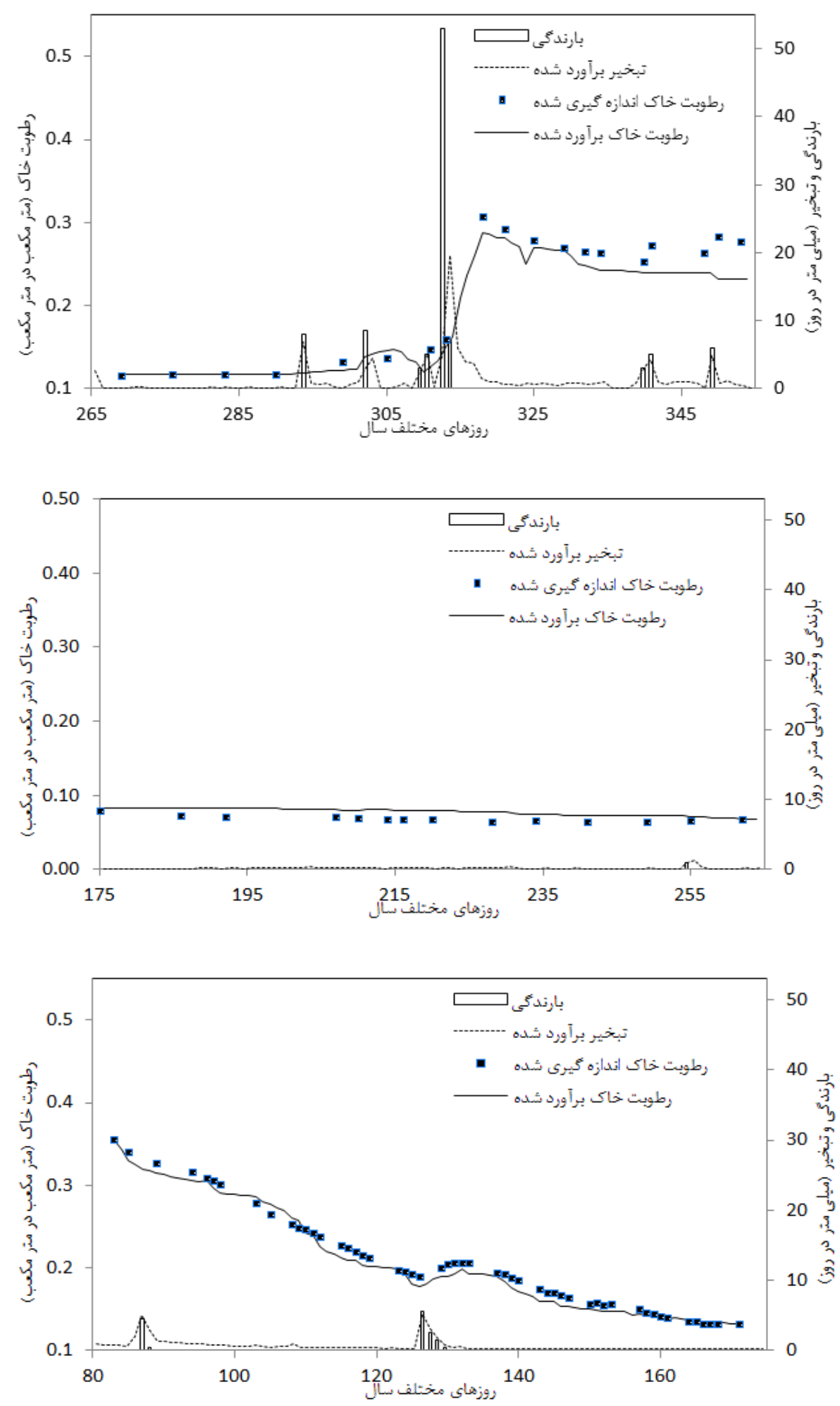

شكل r. مقادير بارندگى، تبخير، رطوبت خاك اندازگيرى شده و بر آورد شده با منظور كردن بارامترهاى بهينه شده هيدروليكى در مدل SWCT 

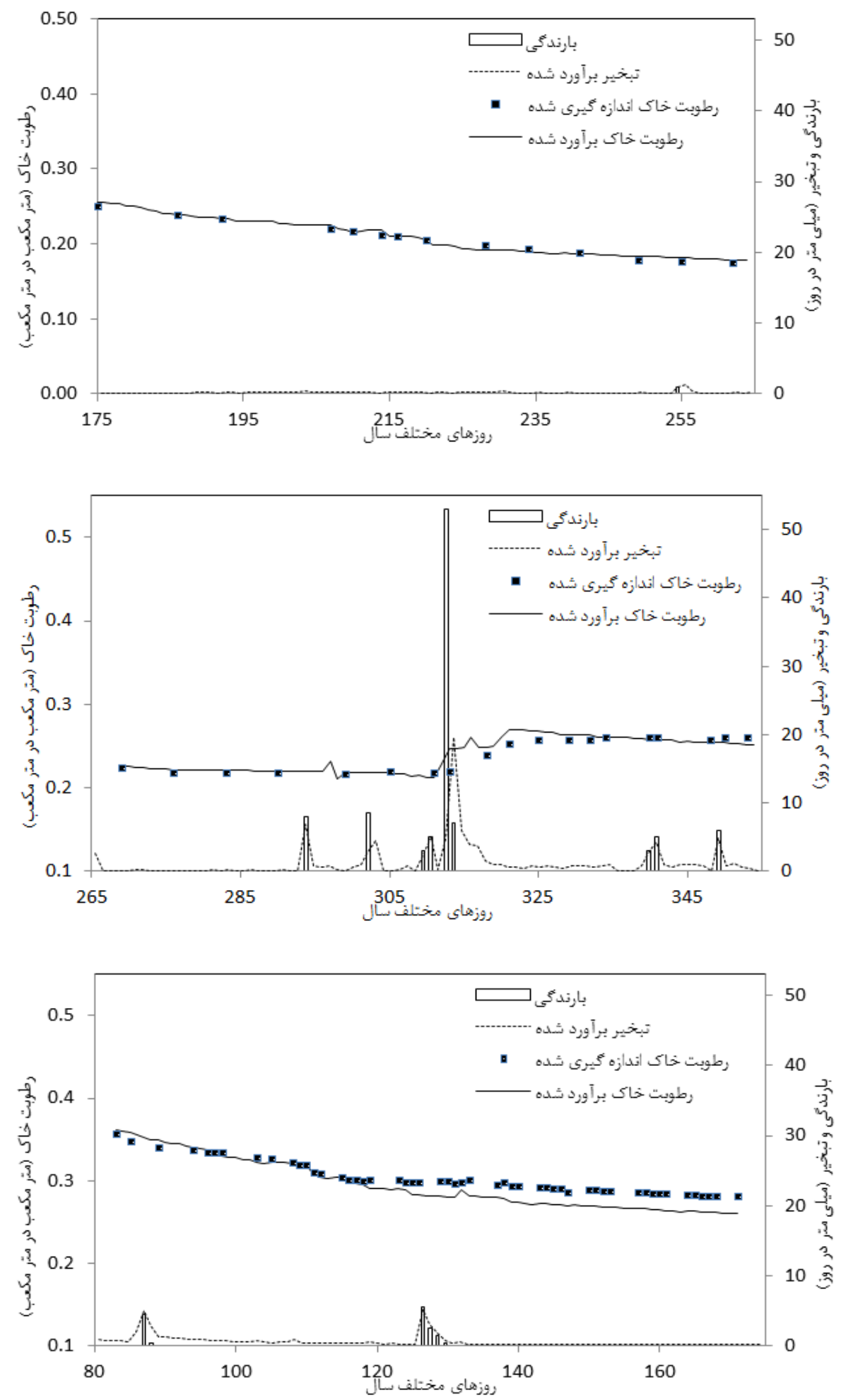

شكل r. مقادير بارندگى، تبخير، رطوبت خاك اندازهيرى شده و برآورد شده با منظور كردن يارامترهاى بهينه شده هيدروليكى در مدل

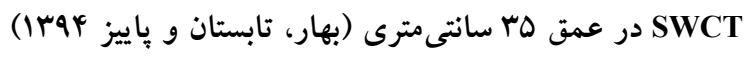


نشريه علوم آب و خاك (علوم و فنون كثاورزى و منابع طبيعى) / سال بيست و دو / شماره يك/ بهار IraV
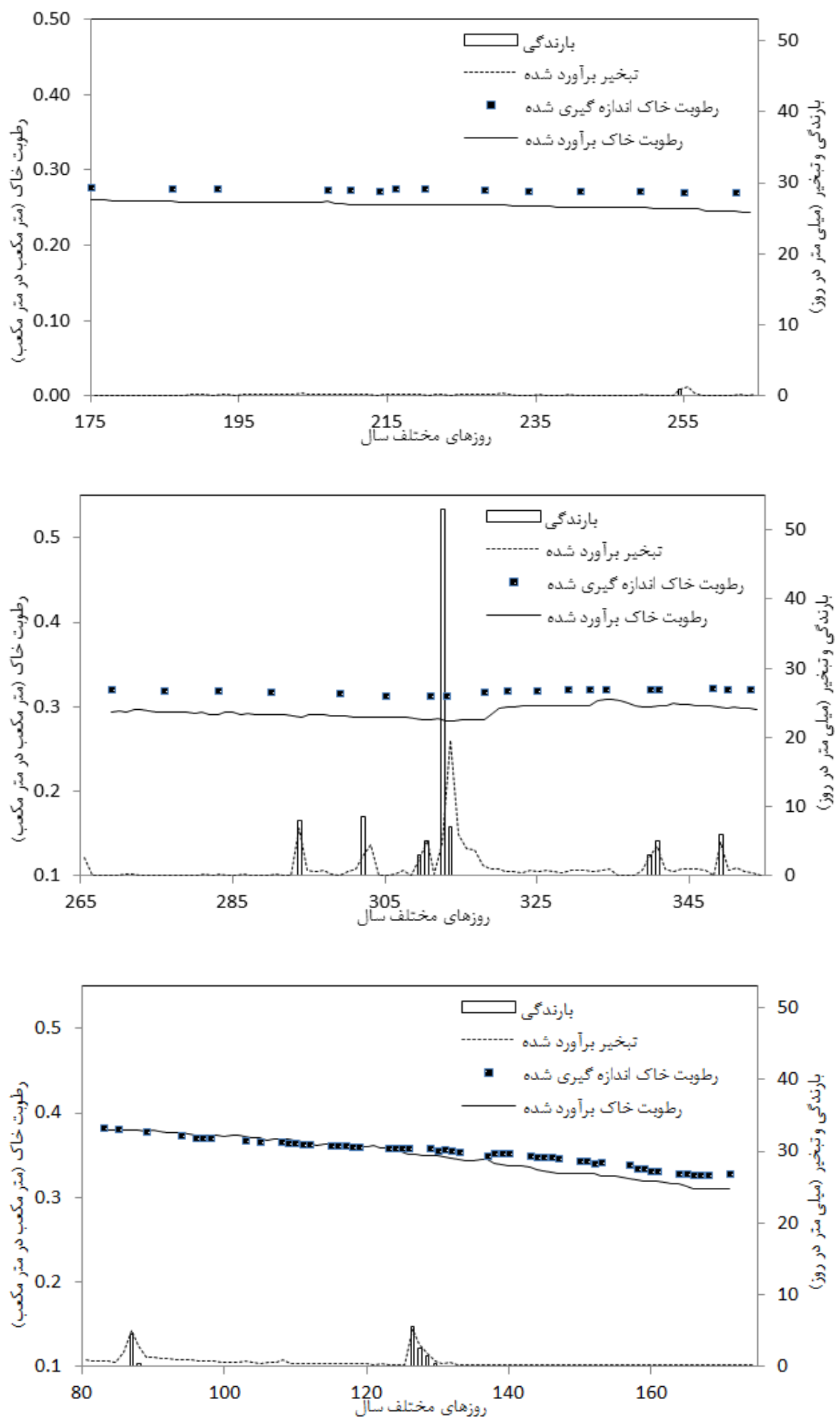

شكل †. مقادير بارندگى، تبخير، رطوبت خاك اندازگيرى شده و برآورد شده با منظور كردن بارامترهاى بهينه شده هيدروليكى در مدل

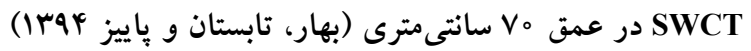


جدول r. نتايج آزمون آمارى رطوبت خاك در اعماق مختلف خاك با در نظر گرفتن حركت بخار آب در خاك

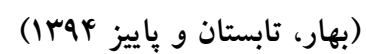

\begin{tabular}{|c|c|c|c|}
\hline عمق & MBE & \multirow{2}{*}{ NRMSE } & \multirow{2}{*}{$\mathrm{d}$} \\
\hline$(\mathrm{cm})$ & $\left(\mathrm{m}^{r} \mathrm{~m}^{-r}\right)$ & & \\
\hline 0 & $-0 / 000$ & $0 / 090$ &.$/ 990$ \\
\hline ro & $-0 / 014$ & 01099 &.$/ 199$ \\
\hline$v_{0}$ & $-0 / 01 r$ & $\% \Delta \Delta 9$ & - /NGK \\
\hline
\end{tabular}

جدول r. نتايج آزمون آمارى دماى خاك در اعماق مختلف خاك با در نظر گرفتن حركت بخار آب در خاك

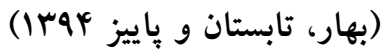

\begin{tabular}{cccc}
\hline MBE & RMSE & $\mathrm{d}$ \\
\hline$(\mathrm{cm})$ & $\left({ }^{\circ} \mathrm{C}\right)$ & $\left({ }^{\circ} \mathrm{C}\right)$ & \\
\hline 0 & $1 / 000$ & $r / 000$ & $0 / 990$ \\
10 & $0 / V 1 r$ & $1 / 1 V 0$ & $0 / 994$ \\
$r \Delta$ & $0 / 9 V 0$ & $1 / 4 V 4$ & $0 / 919$ \\
\hline
\end{tabular}

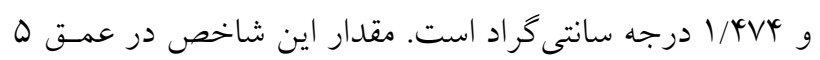

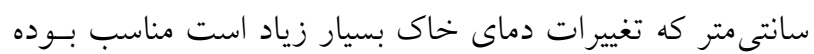

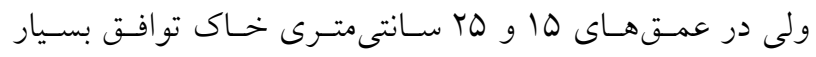

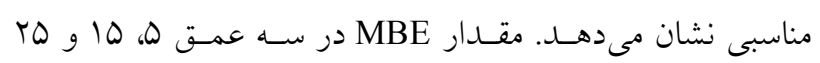

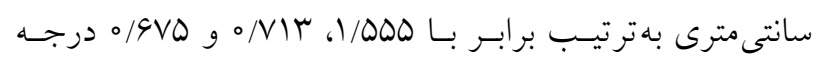

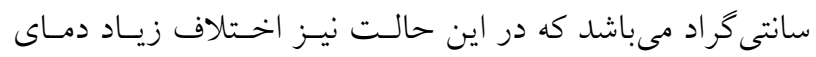

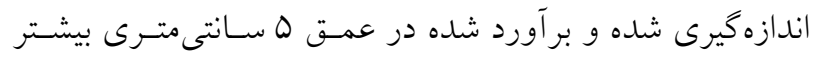
خود را نشان مىدهد و در دو عمق ها و ها سانتى مترى خـاك

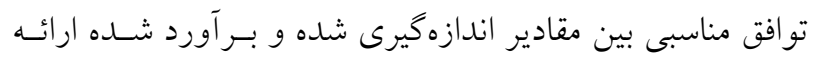

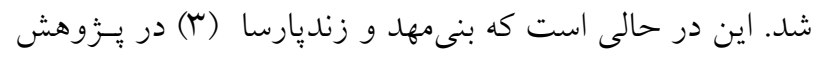

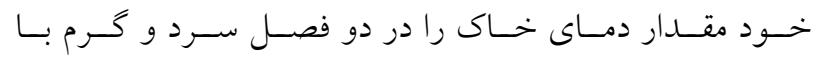

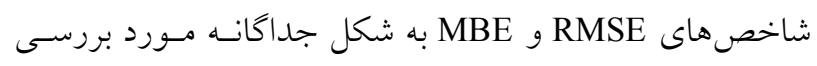

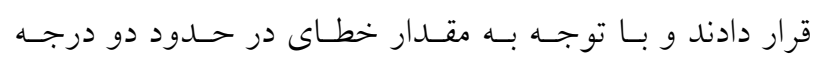

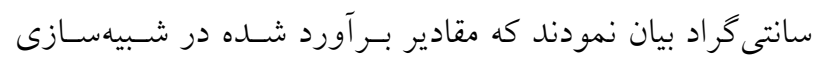

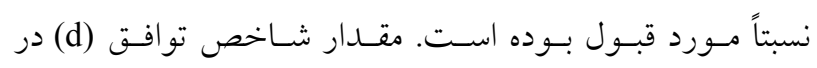

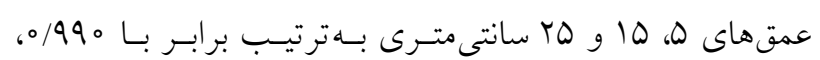

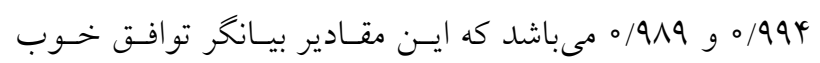

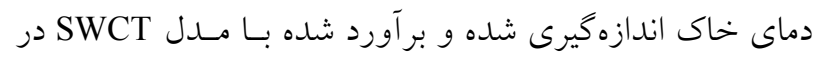

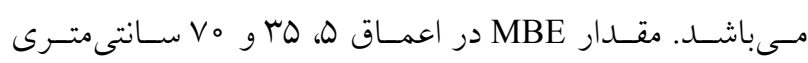

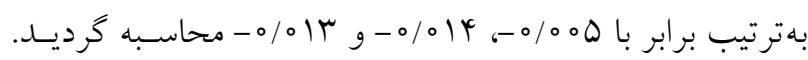

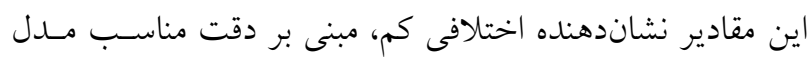

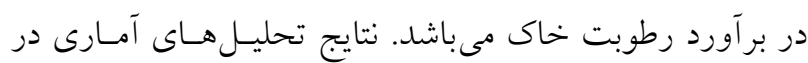
جدول (r) آورده شده است.

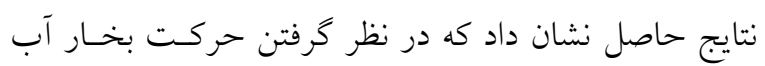
در لايه سطحى روى رطوبـت خـاك تـأثير دارد. زيـــا در لايـهـ سطحى، مقدار رطوبت خاك به اندازهاى كم مىشود كه مىتواند

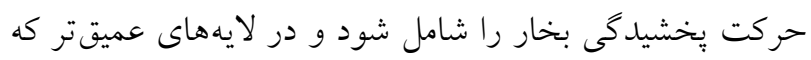
درصد رطوبت خاك بيشتر اسـت حركـت بخـار آب در مقــدار رطوبت خاك، تأثير قابل ملاحظهاى ندارد.

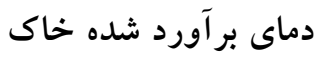

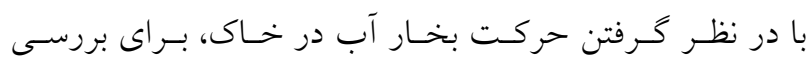

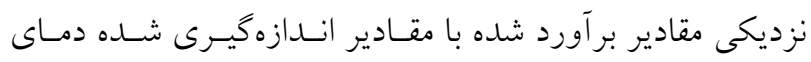

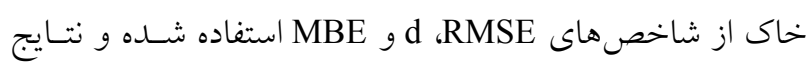

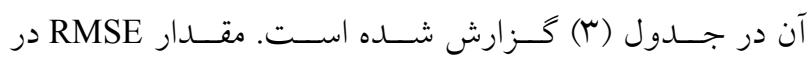

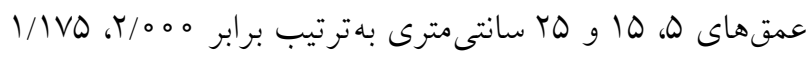




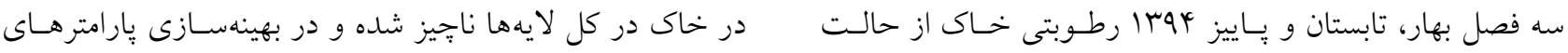

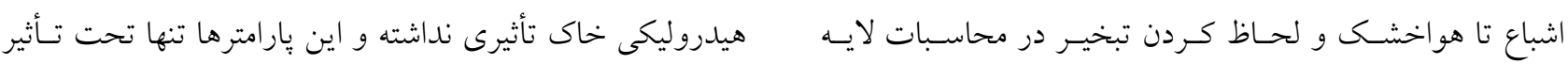

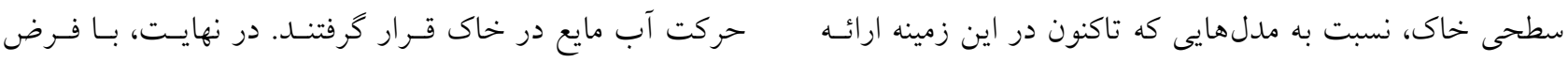

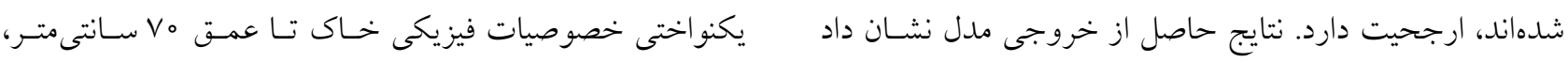

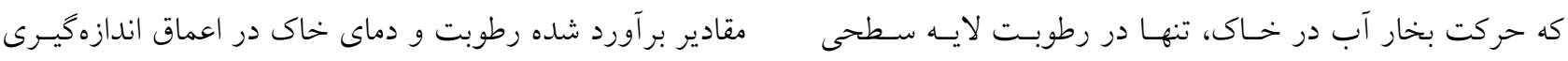

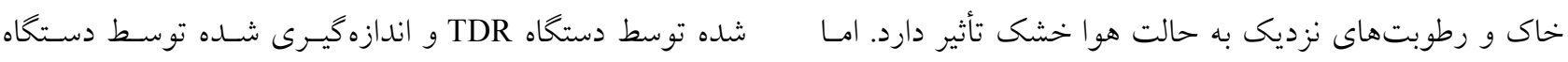

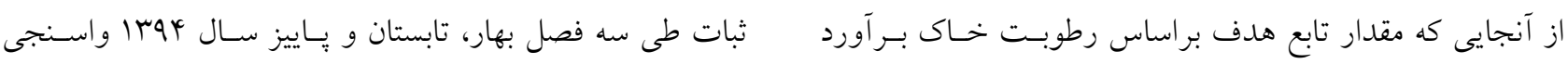

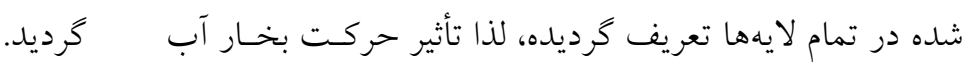

منابع مورد استفاده

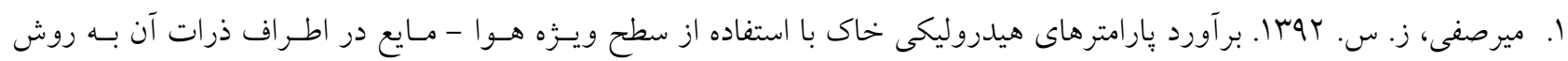

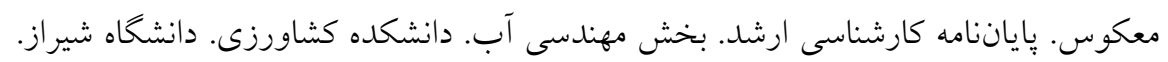

2. Allen, R. G., L. S. Pereira, D. Raes and M. Smith. 1998. Crop evapotranspiration-guidelines for computing crop water requirements. Irrigation and Drainage Paper 56. FAO, Rome, 300(9), 1-15.

3. Banimahd S. A. and Sh. Zand-Parsa. 2013. Simulation of evaporation, coupled liquid water, water wapor and heat transport through the soil medium, Agric. Water. Manage. 130: 168-177.

4. Barber, S. A. and J. B. Peterson.1995. Soil Nutrient Bioavailability a Mechanistic Approach. John Wiley and Sons. New Yourk.

5. Boulet, G., I. Braud and M. Vauclin. 1997. Study of the mechanisms of evaporation under arid conditions using a detailed model of the soil-atmosphere continuum. Application to the EFEDA I experiment. J. Hydro. 193(1): 114141.

6. Brutsaert, W. 1982. Evaporation into the Atmosphere: Theory, History, and Applications D. Reidel Publ., Dordrecht, the Netherlands.

7. Hillel, D. 1998. Environmental Soil Physics: Fundamentals, Applications, and Environmental Considerations. Academic Press. Amrica.

8. Kamali, H. R. and Sh. Zand-Parsa. 2016. Optimization of a new inverse method for estimation of individual soil hydraulic parameters under field condition. Transactions of the ASABE. 95:1-10.

9. Mahbod, M. and Sh. Zand-Parsa. 2010. Prediction of soil hydraulic parameters by inverse method using genetic algorithm under field conditions. Archives Agro. Soil Sci. 56(1): 13-28.

10. Noborio, K., K. J. McInnes and J. L. Heilman. 1996. Two-Dimensional Model for Water, Heat, and Solute Transport in Furrow-Irrigated Soil: I. Theory. Soil Sci. Soc. Am. J. 60(4): 1001-1009.

11. Richards, L. A. 1931. Capillary conduction of liquids through porous mediums. J. Appl. Phy. 1(5): 318-333.

12. Saito, H., J. Simunek and B. P. Mohanty. 2006. Numerical analysis of coupled water, vapor, and heat transport in the vadosezone. Vadose. Zone J. 5: 784-800.

13. Van Bavel C. H. M. and I. Hillel. 1976. Calculating Potential and Actual Evaporation From a Bare Soil Surface by Simulation of Concurrent Flow of Water and Heat. Agricul. Meteo. 17:453-476.

14. Van Genuchten, M. Th. 1980. A Closed-From Equation for Predicting the Hydraulic Conductivity of Unsaturated Soils. Soil Sci. Soc. Am. J. 44: 892-898.

15. Willmott, C. J. 1981. On the validation of models. Phys. Geogr. 2: 184-194.

16. Yang X. and X. You. 2013. Estimating parameters of van genuchten model for soil water retention curve by intelligent algorithms. Appl. Math. Inf. Sci. 7(5): 1977-1983.

17. Zand-Parsa, Sh. 2001. A simulation model for prediction of water and nitrogen effects on corn yield. PhD. Thesis. Irrigation Department, Shiraz University. 


\title{
A New Method for Estimating Hydraulic Parameters by Measuring Soil Moisture in the Field
}

\author{
Sh. Zand-Parsa*, S. Parvizi, A. R. Sepaskhah and A. A Kamgar Haghighi
}

(Received: Sept. 24-2016; Accepted: April 18-2017)

\begin{abstract}
In this study, the values of moisture and soil temperature were estimated at different depths and times under unsteady conditions by solving the Richards' equation in an explicit finite difference method provided in Visual Studio C\#. For the estimation of soil hydraulic parameters, including $a_{v}$ and $n_{v}$ (coefficients of van Genuchten's equation) and $K_{s}$ (saturated hydraulic conductivity), soil moisture and temperature at different depths were measured by TDR probes and the stability apparatus, respectively. The objective function [equal to Root Mean Square Error (RMSE)] was minimized by the optimization of a parameter separately, using the Newton-Raphson method, while, the other parameters were considered as the constant values. Then, by replacing the optimized value of this parameter, the same was done for other parameters. The procedure of optimization was iterated until reaching minor changes to the objective function. The results showed that soil hydraulic parameters (coefficients of van Genuchten's equation) could be optimized by using the SWCT (Soil Water Content and Temperature) model with measuring the soil water content at different depths and meteorological parameters including the minimum and maximum temperature,, air vapor pressure, rainfall and solar radiation. Finally, the measured values of soil moisture and temperature were compared to the depth of $70 \mathrm{~cm}$ in spring, summer, and autumn of 2015. The values of the normalized RMSE of soil water content were 0.090, 0.096 and 0.056 at the soil depths of 5,35 and $70 \mathrm{~cm}$, respectively, while the values of the normalized RSME of soil temperatures were $2.000,1.175$ and $1.5^{\circ} \mathrm{C}$ at these depths, respectively. In this research, the values of soil hydraulic parameters were compared with other previous models in a wider range of soil moisture varying from saturation to air dry condition, as more preferred in soil researches.
\end{abstract}

Keywords: SWCT model, Objective function, Inverse method, Soil water content, Soil temperature.

1. Dept. of Water Eng., Faculty of Agric., Shiraz Univ., Shiraz, Iran.

*: Corresponding Author, Email: zandparsa@yahoo.com 